Border Regions Series

\title{
COMMUNITY, CHANGE AND BORDER TOWNS
}

H. Pınar Şenoğuz

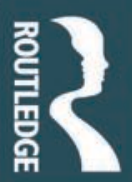




\section{Community, Change and Border Towns}

This book provides an interdisciplinary approach to power, inclusion/exclusion and hierarchy in a Turkish border town, with a focus on the impact of nation-state border on social stratification and change.

Through the lens of ethnographic research and oral history, the book explores social mobility among various strata within the context of transition from Ottoman rule to the Republican regime, in order to reveal culturally informed strategies of border dwellers in coming to grips with new border contexts. It is suggested that the border perspective will move the social analysis beyond "methodological territorialism" and provide a theoretical framework that explores social change at the intersection of local, national and transnational processes.

This book will appeal to readers interested in borders and circulations, social structure and power relations in border regions, as well as transnational shadow networks in the Turkish/Middle Eastern context. The book is a valuable resource for students and scholars of border anthropology, political and economic geography, studies of globalization and transnationalism, anthropology of illegality and Turkish and Middle Eastern studies. It will be a useful grounding for humanitarian professionals who are learning about the social and economic landscape of border towns.

H. Pınar Şenoğuz is currently a post-doctoral fellow at the University of Göttingen in Germany. Until she was dismissed by the emergency decree in 2016, she taught sociology in a public university in Gaziantep city on the Turkish border with Syria. Among her published and forthcoming articles, she explores shadow markets and illegality, post-migration conflicts and refugee hospitality in the southeastern border regions of Turkey. Her research interests include the anthropology of borderland and illegality, border politics and refugee reception policies in EU and Middle Eastern countries, and power and in/exclusion in the Middle East. 


\section{Border Regions Series \\ Edited by Doris Wastl-Walter \\ University of Bern, Switzerland}

In recent years, borders have taken on an immense significance. Throughout the world they have shifted, been constructed and dismantled, and become physical barriers between socio-political ideologies. They may separate societies with very different cultures, histories, national identities or economic power, or divide people of the same ethnic or cultural identity.

As manifestations of some of the world's key political, economic, societal and cultural issues, borders and border regions have received much academic attention over the past decade. This valuable series publishes high quality research monographs and edited comparative volumes that deal with all aspects of border regions, both empirically and theoretically. It will appeal to scholars interested in border regions and geopolitical issues across the whole range of social sciences.

\section{The Politics of Good Neighbourhood}

State, Civil Society and the Enhancement of Cultural Capital in East Central Europe

Béla Filep

\section{European Borderlands}

Living with Barriers and Bridges

Edited by Elisabeth Boesen and Gregor Schnuer

Ethnicity, Gender and the Border Economy

Living in the Turkey-Georgia Borderlands

Latife Akyüz

\section{Community, Change and Border Towns}

H. Pinar Şenoğuz

For a full list of titles in this series, please visit www.routledge.com/geography/series/ASHSER-1224 


\title{
Community, Change and Border Towns
}

\author{
H. Pınar Şenoğuz
}

\author{
Routledge \\ 㖞 Taylor \& Francis Group \\ LONDON AND NEW YORK
}


First published 2019

by Routledge

2 Park Square, Milton Park, Abingdon, Oxon OX14 4RN

and by Routledge

711 Third Avenue, New York, NY 10017

Routledge is an imprint of the Taylor \& Francis Group, an informa business

(C) 2019 H. Pınar Şenoğuz

The right of H. Pınar Şenoğuz to be identified as author of this work has been asserted by her in accordance with sections 77 and 78 of the Copyright, Designs and Patents Act 1988.

All rights reserved. No part of this book may be reprinted or reproduced or utilised in any form or by any electronic, mechanical, or other means, now known or hereafter invented, including photocopying and recording, or in any information storage or retrieval system, without permission in writing from the publishers.

Trademark notice: Product or corporate names may be trademarks or registered trademarks, and are used only for identification and explanation without intent to infringe.

British Library Cataloguing-in-Publication Data

A catalogue record for this book is available from the British Library

Library of Congress Cataloging-in-Publication Data

A catalog record has been requested for this book

ISBN: 978-0-8153-5884-8 (hbk)

ISBN: 978-0-8153-5885-5 (ebk)

Typeset in Times New Roman

by Sunrise Setting Ltd, Brixham, UK 
To Nejat

(Paramaz Kızılbaş)

and all the beautiful people

who fought without borders for humanity

whose imagination had no bounds 
$\because$ Taylor \& Francis

Taylor \& Francis Group

http://taylorandfrancis.com 


\section{Contents}

List of illustrations $\quad x$

Acknowledgements $\quad$ xi

Introduction 1

Porous border, strangled dwellers 2

Historical and ethnographic context 4

Fieldwork on the border 7

Conceptual framework 11

Presentation of chapters 16

1 Exploring community and change from border perspective

Borders as liminal spaces 22

Borders as margins 24

Resituating the study of borderlands 28

Studying borders in Turkey and the Middle East: the challenge

of limited research 31

Concluding remarks 33

\section{PART I}

Traditional notables

2 Eşraf and esnaf: local notables and drawing social boundaries

Who represent the notables? Problems in identifying notable families 42

The story of an eşraf mansion: unwanted citizens, muted histories 53

Concluding remarks 56 
3 Fall from grace: the decline of traditional landed notables

Struggling to maintain status distinctions 61

Beyond the border: eşraf losing ground 65

"We lived like a cicada and they worked like ants": new encounters between eşraf and esnaf 71

"There was no border": nostalgia for the home-place 76

Concluding remarks 80

\section{PART II}

New wealth and the middle class

4 Wealth generation and the rise of new rich in the margins of economy and state

Story of a barber: smuggler, crime boss and businessman 88

Wealth generation in the margins of economy and state 91

Upward mobility at the intersection of small-scale trade and transnational crime 94

Concluding remarks 97

5 Kilis as "little Beirut", markets and illegality

Shadow economy carving out the new urban and social landscape 101

Scale-up of shadow market from local to national 104

Morality of smuggling 107

Shadow economy and order of things at the border 109

Concluding remarks 112

\section{PART III}

Rural and urban poor

$6 \quad$ Peasantry turning into border laborers

Independent peasantry in Kilis 119

Border economy and new relations of dependency 123

Cross-border trade: blurring the boundaries of legal and illegal 128

Concluding remarks 131

7 "The border gate will not ever be closed": livelihoods, aspirations, and reciprocity among the poor

Border laboring in the neoliberal order 136

Giving bribes, taking brides: the politics and economy of kinship among the poor 149

Concluding remarks 155 
Epilogue: war spillovers on Kilis borderland

Shifting demographics in the town 169

Welcoming the Syrian refugees 172

Humanitarian-military nexus at the border 174

Labor markets, war economy and new trade geographies 177

Concluding remarks 181

Appendix

Index

193 


\section{Illustrations}

\section{Figures}

0.1 A prayer break in the border village of Kurd Dagh 11

4.1 A modern minaret added by the barber as a philanthropic activity, $1978 \quad 89$

5.1 Arcade shops left idle 105

6.1 Mudbrick houses in a lowland border village 121

Maps

0.1 Cuinet's map showing Kilis as district (kaza) of Aleppo province, 1835

5.1 Urbanization in the historic town center 


\section{Acknowledgments}

The book draws on my doctoral study presented to the Department of Sociology of Middle East Technical University in Ankara. I would not have been able to finish it without the support of many people from whom I found strength and determination. I am greatly indebted to my advisor Ayşe Saktanber for her sustained understanding and support, and her guidance with the fieldwork. From her, I have also learned to do justice to one's own intellectual endeavors and not to let oneself yield to the discouragements. I am also thankful to her for opening up new questions and arousing my interests for further research with her valuable comments about my study. In her coordination, the study received support from the department of Scientific Research Projects in Middle East Technical University Grant No: BAP-07-03-2011-109. I would also like to thank Umut Beşpınar, H. Deniz Yükseker, Helga Rittersberger-Tılıç and Suavi Aydın, who sat in the defense committee, for their comments which helped to crystallize my arguments.

I owe gratitude to many people who facilitated my field research. Hülya Saygll not only provided me with the most comfortable conditions for a longer stay, but she became a friend and companion with whom I could share many memories about life in Kilis town. Sıdıka Bebekoğlu was a sister and companion who generously shared her knowledge and gave support. Town inhabitants, whose names I cannot list here, showed hospitality, offered solutions when I tackled the problems of daily life during my stay and gave support to my research by sharing their networks. I am thankful to all.

I am grateful to my friends Başak Can, Pınar Yanardağ, Esra Baloğlu, İlker Kabran and Figen Işık. Friends from the Sociology Department kept my academic commitments alive. Among them, I owe particular gratitude to Selda Tuncer. Without her, I would not be able to come through the rigors of scholarship. I am also thankful to my parents, brother and sister-in-law for their endless support. I would like to conclude with special thanks to my life partner Serhat and our six-year-old Vera. They are my 'home' since the failing peace prospects and warmongering on the rise in my country forced us to move away without a chance yet to revisit. I found love and compassion at home whenever I grappled with emotional setbacks. Vera's persistent cheer and sense of pride for this book, though her dream to include her paintings in the book did not come true, was my greatest source of motivation. 
$\because$ Taylor \& Francis

Taylor \& Francis Group

http://taylorandfrancis.com 


\section{Introduction}

Borders demarcate nations. They produce belonging. Borders delimit our worlds and give meanings. They define our places in society, to where and whom we feel attached. But they also offer challenges. We push ourselves beyond our borders and seek to free ourselves from limitations, to change our lives in a better direction or at least manage a life that we think is worth living. This book aims to highlight the place of borders in our lives, by pointing to an actual border setting at the southeastern margins of Turkey. I present the story of the transformation of Ottoman Kilis into a border town, as told from the perspective of its dwellers. Drawing on historical and anthropological approaches, I explore the processes and dynamics that transformed the place into a border town and underline its historicity.

I focus on the impact of border on the cultural and economic landscape of Kilis, a town which has been identified as nowhere in Bilad al-Sham, ${ }^{1} 1$ but as a border town after the establishment of the Republic, inconspicuous for a long time, yet it recently gained prominence with the eruption of the Syrian crisis in 2011 as opposed to other Eastern and Southeastern border towns. The overriding question of the book concerns the ways in which the border influences the life prospects of town dwellers. Border affects socio-economic strata by introducing new territorial, cultural, and economic barriers that they have to accommodate. The first set of questions concerns the ways in which the border shapes the living of socio-economic strata by severing and shifting their cross-border ties. In what ways do border-induced changes such as loss of land properties, shifting routes of trade and status of goods crossing the border, binational relations of kinship affect families at the border? How do these changes alter the class and status relationships among the strata themselves?

Yet, this book is structured around an overriding question that allows room for the structure (border) and agency (dwellers) dialectics. The impact of the border on dwellers from various strata is not only constraining, but it is also enabling them. This book adopts a framework that inquires about the impact of border on dwellers as well as dwellers' capacity to manipulate and circumvent it, providing room for portraying them beyond being mere victims of state policies. It argues that dwellers can utilize the border as an economic resource, by seeking shelter across and evading legal liabilities to the state and its territorial control. Thus, the 


\section{Introduction}

main objective of the thesis is to recognize and make visible the struggles and adaptations of dwellers to the border.

While border introduces new distinctions, it also offers new opportunities of encounter and contact across the border. Therefore, I argue that the second set of questions that should be asked must highlight the ways in which socio-economic strata adjust to the border by developing new networks and connections. What sorts of mechanisms and linkages do they develop to rely on? How do they manipulate and circumvent the territorial as well as cultural and economic barriers? In what ways do these shifts in the cross-border ties contribute to the social stratification structure by redrawing class boundaries?

A town is not just designated a border town by being adjacent to the border but as it is argued by Buursink, "it also came into existence because of the border" (Buursink, 2001, pp. 7-8). The processes and dynamics at the border regulate the border-crossing of people, animals, and goods in ways to enable their movement or halt it and, thus, produce different mobilities and enclosures for socio-economic strata, which they have to accommodate in various ways. I assume that movement/ enclosure at the border inflicts its dwellers with values, practices, and relationships that are not found anywhere else in the nation-state and creates "the border experience" (Martinez, 1994) that is often marginalized by social analyses.

Through the lens of ethnographic research and oral history, I explore belonging and social mobility among various socio-economic strata within the context of transition from Ottoman rule to the Republican regime because it will help me to reveal the impact of border on the cultural and economic landscape of Kilis. The aim of the book is to account the social change with the shift of Kilis, an Ottoman inland frontier and a resettlement area for Arabic, as well as Kurdish and Turcoman tribes accused by the Ottoman central power of "political banditry" (Soyudoğan, 2005) into a modern nation-state border. For substantiating my research question, I introduce a theoretical framework that explores the social change in a border town at the intersection of local, national, and transnational processes. I suggest that the border perspective will move the analysis beyond "methodological territorialism" (van Schendel, 2005) that encapsulates the social analysis into the idea of nation-state as unit of analysis. From the vantage point of border, I will demonstrate that social reproduction and social mobility strategies of families in Kilis are incorporated in the broader cultural, social, and economic transformation of Turkey long before globalization started to put limitations to the state sovereignty and territorial control.

\section{Porous border, strangled dwellers}

Kilis border town, a small province in southeastern Turkey, has become known worldwide lately due to the extensive news coverage of the Syrian conflict by the world media. Located at the Turkish-Syrian border and presently contiguous to a territory of war and mass demolition, the name of this border town, as well as other towns on the border, probably circulates among United Nations (UN) staff, international non-governmental organization (NGO) employees, government 
officials, and state bureaucrats. When a flow of migrants along the Turkish border started, the prefabricated camp in Kilis located at the zero point on the border was turned into a showcase for the Turkish government in order to present to the world that it does whatever it can to take care of the human crisis and to accommodate its Syrian guests. ${ }^{2}$ The names who paid initial visits to Kilis camp for Syrian migrants in 2012 include UN special envoy for Syria and former UN general secretary Kofi Annan, UN goodwill ambassador Angelina Jolie and the then Prime Minister Recep Tayyip Erdoğan. The visit of Erdoğan seemed to target the attention of world politicians concerned with the plight of Syria as he gave a speech to the migrants, heralding them their victory against the Assad regime in Syria and warning Bashar al-Assad (Kibritoğlu \& Çelebioğlu, 2012).

In contrast to the global attention transforming Kilis into a hub of movement, the incoming Syrian migrants simply accentuate for the town dwellers their sense of containment at the border. A local man picturesquely explains it to me by imagining the town as a place squeezed between two stakes at the opposite corners of the town's administrative boundaries with its adjacent city Gaziantep in the north-northwest. He refers to two villages, both named Kazıklı, meaning literally "with pales" in order to portray the town as a territory nipped from its two corners as if impaled and made into a confined place because once you enter the town's boundaries, you have nowhere to go because of the enclosing border with Syria. He says: "We are squeezed between two Kazıklis."

The increase of "global flows" shapes every corner of the world but in different ways. Globalization creates new spatial inequalities that highlight class disparities beneath them despite its promise towards a borderless world. Although the world is shrinking through a web of communications and exchanges, and geographical movements across the globe seem to defeat the territorial borders of nation-states, there are a great number of people with feelings of confinement and immobility at border geographies in an increasingly globalizing world. Border scholars Hillary Cunningham and Josiah Heyman suggest that the theme of mobility is intrinsic to the questions of power, justice, and inequality (Cunningham and Heyman, 2004 , p. 294). For them, mobility, as well as enclosure are "vital to the exploring relationships of differentiation across space" (Cunningham and Heyman, 2004, p. 295). I believe that these points are illustrated in the above-mentioned feeling of being squeezed, expressed by the local man in Kilis.

I have carried out field research in Kilis town between January 2011 and June 2012. The Syrian uprising that broke out in March 2011, three months after I started my field research, had been a challenge for me that made me think more about the sense of containment prevalent among Kilis dwellers. The dwellers depicted the town as devoid of industrial investment and vibrant cultural life, especially after the urban elite had deserted. The border is portrayed as a physical hindrance, an obstacle to the industrial development of the town because, without infrastructure and good highway connections to its surrounding ports and business clusters, it lacks the viable conditions for attracting investment. Kilis was for the dwellers a socio-economic and cultural margin. Culturally, town dwellers have as much attachment across the border as they have with their co-nationals. 
Economically, cross-border trade can be a viable option for livelihood and a better life and yet it puts them in jeopardy of criminalization.

As the Syrian opposition grew larger in their struggle to depose of the Assad regime, I bewilderedly kept a close watch on the reactions of local residents. While the national media coverage highlighted the armed conflict and civilian deaths, the dwellers of Kilis continued to argue that the news included exaggeration and there were no such grave conflicts. Eventually, the arguments get varied in that the protests went beyond purpose and the son Assad was actually a good leader, that imperialist forces wanted to create trouble in order to realize their Great Middle East Plan and that Turkey is being trapped by these forces. The prime minister's statement that the Syrian unrest was their internal affair aggravated local fears that the government's attitude would hinder cross-border trade, which was the source of livelihood for a significant number of dwellers. Hence, the incoming of Syrian migrants as well as solidarity actions by local and international NGOs with Syrian opposition in Kilis was met with the resistance of the town community.

Soon after I finished my field research and left the town, the Turkish government closed its border with Syria for security reasons and banned the exit of Turkish citizens. In the Kilis case, it is possible to observe that the globalization framework created new conflicts and spatial arrangements that the town dwellers now have to accommodate. Thus, the emphasis on the global flows and border crossings highlighting mobility may overshadow how these movements enclose spaces of exchange and livelihoods and produce immobility for certain groups.

Not only trade relations, but also other sorts of cross-border exchanges, relations of trust, straddling forms of living such as cross-border labouring or land tenure, kinship, familial alliance and ethnic affinity historically characterized the Kilis border. Transborder movement was part of everyday life, making the dwellers differ from a broader population that is not located adjacent to an interstate border. Then why are the town dwellers engulfed in a strong sense of containment? Paradoxical though it may seem, the border experiences of dwellers cannot be understood without superimposing their sense of containment with the porosity of the Kilis border. This is a question worth thinking about, indicating how volatile and vulnerable life at the border could be.

\section{Historical and ethnographic context}

Prior to the Syrian war, Kilis was a border town with a population of about 130,000 located on the Turkish-Syrian border, hosting ethnically Turcoman, Arab, and Kurdish groups with kinship bonds extending to the Syrian side. In the Ottoman Empire, Kilis was an inland frontier for these nomadic tribes, sedentarized by the central authority since the late seventeenth century (Kasaba, 2004). Kilis region also marked the beginning of the Arab provinces of the Ottoman Empire, as distinguished from the Anatolian lands. While the Turkish-Syrian border was delineated between Turkey and France with the Ankara Agreement of 1921, it has been disputable for the Turkish side since the beginning. According to Güçlü, the political boundaries of Syria did not exist prior to the Sykes-Picot agreement, known 
as a secret alliance between Britain and France in 1916 to define their spheres of influence (Güçlü, 2006, p. 641). But the boundary line nearly corresponded to the assumed linguistic and national boundary of the Turkish area, though it was far northern at its initial demarcation.

When the deputy Ali Cenani from Ayıntap (Gaziantep) made his speech in 1922 on the disputed borderline, he addressed the squeezing of Kilis town by the demarcation of the border. "The line passing just by five kilometer south of Kilis town has rendered that country almost paralyzed," he said (TBMM, 1922, p. 425). The border demarcated in 1921 had torn apart the former Ottoman land from the emerging Republic of Turkey and abandoned north Syria, as well as some of the Kilis agrarian fields to the French Mandate. The provisional delineation of the border was substituted in the meantime by a frontier better suited to the needs of the Turkish side and special regulation of border crossing allowed large landowners to have access to their propriety at the Syrian side. The final delimitation of the border could only be completed with the restoration of Antioch to Turkey in 1939. Big landowning families could continue to claim proprietorship over their lands left at the Syrian side and harvest their crop until their lands were confiscated by the Syrian Baath Party rising in power in 1954 within the context of agrarian reform.

However, the Turkish-Syrian border remains highly contentious in terms of international politics. Regarding the border dispute, the issue was never resolved in the nationalist imagination of linguistic unity because of the significant Turcoman population left in North Syria, particularly in Aleppo and its vicinity. On the other hand, the Cold War policies of the 1950s embraced the border and reinforced it with the wiring and mining of the whole boundary line except Samandağ of Antakya. The rise of the Baath Party in Syria as it won a significant number of parliamentary seats accelerated the political tension between the countries. The background to the tension was the US-led Cold War against the Soviet Union and the American quest to build a transnational security organization in the Middle East against Soviet impact (Baş, 2012). The international relationship between Turkey and Syria was caught in the crisis in 1957 and Turkey dispatched troops to its border. Nevertheless, both Turkey and Syria realized that they would not be able to win without allies in a potential close combat and the political tension loosened.

It is not possible to access the documentation about the mining of the border during 1956-1959. The Turkish government declared that mining of the border was intended to stop smuggling, citing a high-profile incident when smugglers shot two customs agents dead (Köknar, 2004). Nevertheless, the smuggling alone does not explain why the mine laying continued for three years, especially taking into account that illegal trade has actually increased in volume and value after the mining of the border. Moreover, more mines were laid again after the 1980 coup (Özgen, 2010). Mine laying is responsible for many deaths and maimings at the Kilis border.

The Kurdish question and water dispute are two other major sources of political tension. The water dispute goes back to the 1970s as Turkey started the 


\section{Introduction}

construction of water dams within the context of the Southeastern Anatolia Project (GAP) (Olson, 1997). After Abdullah Öcalan, the leader of the Marxist-Leninist insurgency PKK (Partiya Karkerên Kurdistan, Kurdish Workers' Party), found shelter in Syria in the late 1970s, the two issues were played by the countries as trump cards to each other. Yet, Turkey's concern with securing its border against the 'dangerous population' actually dates back to the 1920s and 1930s, and archival sources show that Turkey is quite disturbed with the settlement of deported Armenians, insurgent Kurdish as well as Assyrian and Yazidi emigrants along the Syrian border with Turkey (Altuğ and White, 2009). The Kurdish question between Turkey and Syria found a resolution with the signing of the Adana agreement in 1998 and led Syria to deport the Kurdish leader (Aras and Polat, 2008). But, the emergence of the Kurdish movement in northern Syria and the 2013 declaration of autonomous zones by the Democratic Union Party (PYD) seems to resurrect Turkey's security concerns at its border.

In the light of this brief historical overview, I suggest that international relationships and state politics make the Turkish-Syrian border highly unsettled. I do not only refer to the impact of international politics, but also to the spillovers of internal politics of the states respectively on these borderlands. Despite the ruling Justice and Development Party's (AKP) efforts to mend the fences with Syria until a popular uprising broke out in this country, the relationships between Turkey and Syria have been characterized by boundary disputes, political tensions, and alienation, as well as political negotiations, cooperation seeking, and diplomatic bonds. As part of the Middle Eastern geography, the Turkish border with Syria is characterized by authentic multiculturalism (Doğruel, 2013), ethnic hostility, and religious sectarianism created by nation-state context (Altuğ, 2002), political geographies of ethnic and political divisions (Tuncer-Gürkaş, 2014) and a cosmopolitanism based on multiple and controversial ways of remembering and forgetting the Armenian genocide of 1915 (Biner, 2010).

Local discourses and narratives in Kilis town draw on a historical ethnosymbolism (Canefe, 2002) that utilizes myths of origins and ancestry of Turkish people and memories of a distinct Muslim Anatolian society. The Armenians of Kilis were deported following the 1915 Deportation Law and the Jewish community had completely left by the late 1960s, possibly following the Arab-Israeli conflict in 1967. Local historical accounts emphasize the Turkification and conversion to Islam in the region. ${ }^{3}$ These accounts point to the suppression and assimilation of ethnic and religious identities to the national unification and erasure from the popular imagination of the cultural and historical legacy leftover from the Christian communities.

The ethno-religious assimilation is also apparent in the cultural domination of Sunnite Islam, alienating the Alawite identity. The assimilation of Alawite Turcomans in the Kilis region has its historical roots in their settlement in the midnineteenth-century Ottoman Empire. İlbeyli Turcomans of Kilis are among the tribes converted to Sunnite Islam with strong tribal bonds and identification due to their relatively recent settlement (Aydın, 2011, p. 11). Turcoman villages are located eastwards, where Kilis lowlands are converging with the Turcoman-dominated 
plain of Gaziantep, though these lowlands are studded with Kurdish and Arab populations as well. On the other hand, Kurd Dagh, a highland border region in eastward Kilis, is predominantly populated with the Kurdish population.

Hence, the case of Kilis affirms the argument that the border is not a homogeneous unit and there can be many borderlands along a geopolitical frontier with particular and distinct border cultures (Donnan and Wilson, 1999). This borderland is distinguished from other places along the Turkish-Syrian border as a strong case of assimilation and stability in terms of the ethnic and political conflicts surrounding it. These features of Kilis borderland make the struggles and adaptations of local dwellers to sustain their cross-border ties in the Middle Eastern political geography even more significant. The refugee arrivals do not undermine these features but rather enhance them. The Syrian refugees, as new inhabitants of the town, have soon become integral to these struggles and adaptations.

\section{Fieldwork on the border}

Borders, as margins of the nation-state, are marginalized in official and popular discourses. Depicted as entrenched in the traditional community relationships and underdevelopment, the borders are stigmatized as sites escaping the state order and open to corruption and illegal practices. The borders are also stigmatized by border dwellers. In Kilis, for instance, most of the dwellers associate the border with its unregulated trade and illicit economy. Kilis dwellers notoriously name their efforts to earn a livelihood at the border as "smuggling" and place it at the center of their border perceptions, as if it is the only distinctive characteristics of this border. To put it differently, borders bring their own ideologies, stories, and ways of interaction that the border researcher must delve into in order to explore what living at the border meant to the border dwellers. This might prove rather challenging when this is not legible in the official and archival records, sources of information are not cooperative, or secrecy dominates among the dwellers.

The research consists of 18-months' fieldwork on belonging and social mobility processes among various socio-economic strata in Kilis. Anthropologists classify ethnography as a genre of storytelling, reminding us that our ethnographic works are also narratives transforming the sense of fragmentation, contingency, and dislocation experienced in the field (Bruner, 1986; Rapport, 2000). This book locates the agency of town dwellers in accommodating themselves to the border on the foreground against the view of border dwellers as being mere victims of artificial territorial boundaries drawn by colonial powers in the Middle Eastern context. I explore different strategies adopted by various socio-economic strata to navigate territorial borders and group boundaries. For this purpose, I rely on ethnographic and oral history approaches as well as a reflexive anthropology establishing an intimate rapport with the town dwellers to overcome the challenges of doing fieldwork on the border.

The border context has imperatives that determine the research question as well as strategy. Kilis, as the provincial hinterland of Ottoman Aleppo before the demarcation of the border (see Map 0.1), remained a moderately big town after it 


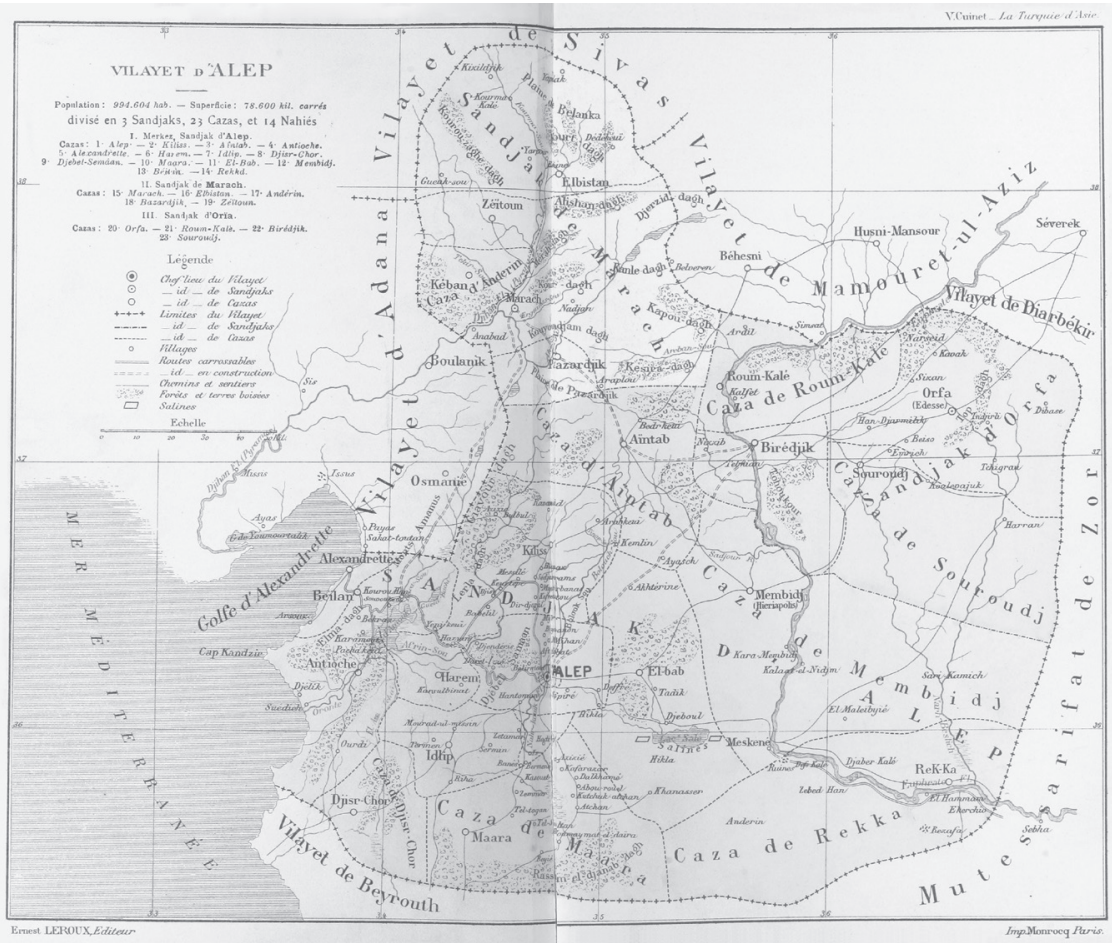

Map 0.1 Cuinet's map showing Kilis as district ( $k a z a)$ of Aleppo province, 1835 (Retrieved from Wikimedia Commons)

became annexed to the city of Gaziantep. The town bears the traces of a highly stratified social structure inherited from the Ottoman landholding class and agricultural production. The cultural and architectural inheritance of long-established notables is still present, though notable families have lost their social and economic power since the 1960s. Even though these families remained among the wealthy strata of the town, I realized their feelings of decline should be interpreted as part of their social mobility experiences with the demarcation and consolidation of the border. The historical background that informs identity formation in this border region indicated that the question of belonging should be addressed by a genealogical study of family histories through Ottoman archives. Life stories of notables conduced towards an inquiry about the ways in which social mobility processes at the border pave the ground for critical belongings and transform the meanings of illegality, wealth, and work, which are inflicted by a border culture difficult to penetrate. This is an important reason why I make much use of participant observation data.

As the method of study, I rely on oral history and ethnographic research supported by in-depth interviews, archival research, as well as trope analysis. Embracing oral 
history within the ethnographic context is not uncommon. Yet, it extends the question of intersubjectivity, that anthropological writing tackles since the 'interpretive turn' (Vila, 2003) after Writing Culture (Marcus and Clifford, 1986), to oral history interviews and renders oral history and ethnographic study alike (Di Leonardo, 1987). However, the added value of oral history interviews, in contrast to in-depth interviews, is that oral history allows the researcher to unravel the past through a multiplicity of standpoints and encompasses the complexity of conflicts (Thompson, 1998). Oral history reveals the silenced and omitted accounts of the past, often shrouded in secrecy by the prevailing modes of history writing, an impact that could be observed not only in the narrating of family histories among Kilis notables but also in the peasants' accounts of their relationships with the notables.

In the total, I conducted 44 recorded (voice recording and note-taking) interviews, including more than one person in a few cases. The interviewees were recruited from a social composition including three socio-economic strata: namely, old wealth, new wealth and middle class, and rural and urban poor (see the Appendix for Interviewee Profiles and Explanatory Notes for Oral History and In-depth Interviews). I define old wealth as traditional landed and trade notables, a status distinction which I discuss in length in Chapter 2 on the notables. New wealth and the middle class are comprised of extended families that are usually - but not necessarily - from a rural background and have moved up among the ranks of the urban middle class. One shortcoming is that I could not recruit interviewees among the small circle of new wealth, who have started to make investments in Istanbul since the mid-1960s and settled there all together after the 1980 coup. I try to meet this deficit by giving a profile of new wealth in Istanbul, by introducing the story of a barber in Chapter 4 on new wealth. Members of new wealth in Istanbul and extended families from a rural background living in Kilis experienced upward mobility through the same mechanisms and wealth-generating practices during the 1960-1980 period of import-substituting industrialization. The new middle class also includes heirs of old notables, whose social reproduction strategies are based on education and urban employment. Finally, I classify the rural and urban poor as lower strata. These interviewees are usually the offspring of independent peasant families or families working at the landlord's household as domestic and casual labourers.

The study recruits a wide arrange of interviewees among local notables, chieftains, tradesmen and shopkeepers, professionals and intellectuals, border villagers, and urban poor. They also include a few former mayors and parliamentarians, which contributed to my understanding of how local political dynamics articulated with the broader border politics. Interviews with officers at governmental and semi-public institutions added to the information about the socio-economic structure and dynamics of social change. Regarding the sectoral composition, the background of interviewees mainly covers agriculture, trade, and transport sectors. When I could not conduct a recorded interview, the interactions and encounters in the field kept a vigilant eye to subaltern voices. These range from casual labourers and unemployed youth to women peddlers and border villagers. I had informal dialogues with groups of high school students, women gatherings, and border villagers. 
There were many cases where I could not take personal information such as age and current profession. But the dialogues gave me important clues about the interviewees' position and status as well as insights about the history and facts about illegal border trade and its impact on the socio-economic structure of the city. Thus, I prefer to give the birth year intervals of five years in order to classify the interviewees along the age groups. Regarding the age scale, old wealth typically included the oldest age groups, with birth years ranging between 1920 and 1955, with the exception of Latife born in 1911. The birth year intervals ranged between 1930 and 1975 for new wealth and the middle strata as they have been interviewed principally about the shadow economy of the import-substituting industrialization period of 1960-1980, except an old-generation woman who could give information about her father's involvement in smuggling livestock as early as the 1940s and a younger transport company owner. The age distribution among the rural and urban poor is almost even as the interviews were concentrated both on the agrarian labour structure between the 1930s and 1960s, and the cross-border trade introduced in the mid-1990s. The book draws much of these ethnographic data offered by the encounters and exchanges with these unrepresented groups.

Recorded interviews were likely to take the form of oral histories about social and economic life. As interviewees were reluctant to talk about the present situation, they were more inclined to talk about the past in order to avoid, for instance, revealing their involvement in illegal trade. While urban notables and the new rich gave accounts of their family life and social history of the town, border peasants and the urban poor narrated their struggle with regard to subsistence and the change in their relationship with the landowning class. The border peasants were also afraid of law enforcement and military surveillance at the border.

Since I have met with difficulties in conducting recorded interviews, I have complemented them with snippets of responses (Vila, 2000, p. 254) and micro-narratives (Doevenspeck, 2011) in order to uncover hidden narratives beneath the dominant stereotypes and prejudices and to approach the everyday experiences and practices at the border. Such pieces of conversations are employed by border studies in inquiring the narrative construction of boundaries, identities, and belonging at the border (Paasi, 2003; Vila, 1997, 2000; Doevenspeck, 2011; Pelkmans, 2006; Flynn, 1997). Putting emphasis on narrativity does not necessarily mean to employ a narrative methodology that applies the procedural set of techniques to relate small-scale stories to the wider context of narratives. Rather, I work with local narratives in order to disclose the 'border talk', i.e. in what ways dwellers talk about the border, which issues and problems they bring to the foreground, why these are being told and not the others. As I refer to in the analysis chapters of this book, the border talk in Kilis town included issues about the demarcation of border and local resistance against the French occupation, trade activities connecting Kilis with trade and finance centers in the region, the use of border as economic resources, and cross-border marriages and kin relationships. These narrative accounts reveal the shifts in power relations experienced in everyday life.

Finally, I support my discussion with reference to a purposive sampling on local and national newspapers in order to study the criminalizing discourses and their possible effects shaping the experiences of border dwellers. During the fieldwork, I 


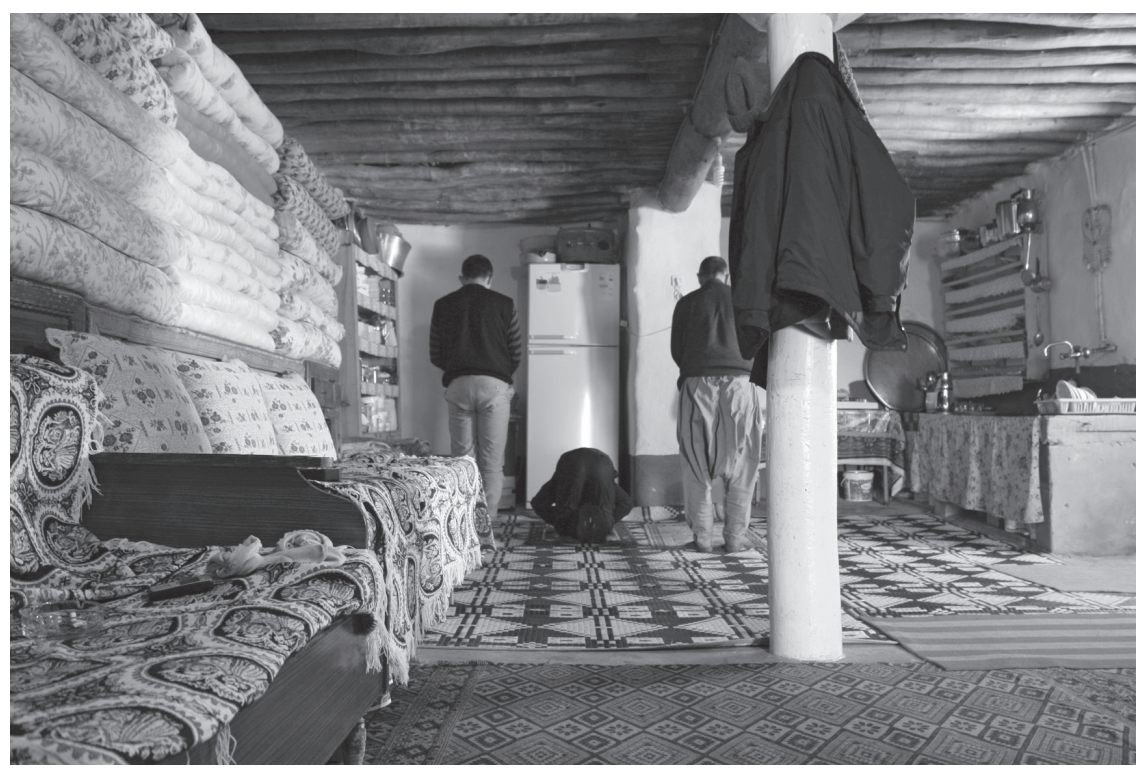

Figure 0.1 A prayer break in the border village of Kurd Dagh (Photo courtesy of the author)

have regularly tried to follow daily news appearing in local papers. There are four local newspapers in Kilis, among which two of them date back to the early Republican period. Although they tend to sound like tabloid press publishing mainly the news circulated by the local police department of anti-smuggling, they reveal the differences of opinion and established alliances among various positions of political adherence. The websites of these newspapers provide virtual forums for readers expressing comments and, thus, they give clues about the public opinion of the local community. The study also draws on archival sources, including international treaties, laws and regulations about border control and customs as well as smuggling, and minutes of parliament meetings. These documents shed light on the official discourses related to controversial issues of border management, the definition of border as a legal category and the criminalization of transgressive activities.

Short visits to the town after I finished my fieldwork allowed follow-up observations about the impact of the Syrian conflict. These visits included professional occasions in October 2012 and March 2016, when I worked as translator-fixer for MSF and Deutsche Welle respectively. I also paid a week-long visit for research in July 2015 and held semi-structured interviews in the town center and border villages of Elbeyli and Kurd Dagh (see Figure 0.1).

\section{Conceptual framework}

Border studies constitute a theoretical background to this study. However, as Paasi (2011) argues, this scholarly literature is not yet an integrated field of study. As 


\section{Introduction}

the researchers of border, we cannot refer to a 'border theory' as groundedly as we may speak of the state theory or theory of social classes. Border studies has been revived as an interdisciplinary realm of investigation under the impact of globalization, but mainly adopted anthropological approaches prioritizing conceptual boundaries rather than territorial borders or even embracing a theoretical framework that puts the territorial borders out of sight. Moreover, as studies on border are proliferating, the understanding of borders are perpetually changing and diverging depending on the research problems addressed and eventually become part of theorization. Nevertheless, research on border is still empirically compartmentalized, largely deprived of historical and comparative analyses.

The conceptual framework of my study combines the arguments produced from within border studies and oral history with the debates on post-Ottoman social stratification in order to provide a transdisciplinary approach to power, hierarchy, and in/exclusion in a particular border region. Oral history and theories of social stratification are methodological imperatives of the research as they substantiate historical analysis with the concept of socio-economic mobility among different strata.

\section{Border, frontier, boundary and borderland}

The literature review in Chapter 1 is fully devoted to highlighting the analytical power of the concepts adopted in this book with reference to border studies. Still, this section shortly introduces some of these concepts.

In this book, the term "border" is used to refer to the territorial and, in the case of Kilis, political boundary. Border drawn between two nation-states is necessarily territorial and cartographic, i.e. delineated on a map. As opposed to the term "frontier", border encloses neighborhood, communities, and nations and turns them into territorially-bounded units. As Strassoldo argues, frontiers are "areas of growth into 'virgin' territories" (Strassoldo, 1980, p. 50). Famously known as Frederick Jackson Turner's frontier thesis, the term frontier is used to denote the territorial expansions of civilizations and empires (Baud and van Schendel, 1997). In other words, frontier does not signify limits or barriers, but openness, expansiveness and dynamism.

A new genre in border studies employs the notion of "borderland" as a focal metaphor to denote a liminal space where two distinct cultures face and counterpose each other (Wilson and Donnan, 1998). The literature review extensively cites the criticisms about the new borderlands genre from within border studies in order elaborate on the approach to "border/land as liminal space." The term "borderland" for this book signifies the "existence and impact of a border on the human landscape" (Newman, 2003, p. 19). It denotes a border location embedded within networks straddling across the territorial border between two or more states (Baud and van Schendel, 1997; Wilson and Donnan, 1998). Embracing the notion of borderland reiterates the fact that the border is more than a line bisecting a geographical space. Constantly shifting, Baud and van Schendel figuratively describes it as an accordion in order to portray contracting and expanding ties radiating at the two sides of the territorial border in response to various 
contentions and strife raised by state politics and transnationalism (Baud and van Schendel, 1997).

Within the realm of border studies, the term "border" and "boundary" could be used interchangeably. In this book, boundaries are associated with communal borders to "signify the point at which "we" end and "they" begin" (Migdal, 2004, p. 5). Contemporary border studies combine the concepts of borders (territorial delimitations) and boundaries (social categorizations) in a single analytical framework to explore the bordering processes, through which, as Newman argues, the categories of difference or separation are created (Newman, 2003). The source of inspiration for this development is the turn to Barth's paradigmatic ideas on ethnic boundaries (Donnan and Wilson, 1999). Instead of defining ethnic identity as a set of features shared by the member of groups, Barth (1969) looked at the inclusion and exclusion processes through which ethnic boundaries are maintained and re-confirmed. Borrowed from Barth, boundaries acquire an analytical power to study apparently unrelated phenomena of boundary-making within the nation and the territorialization and policing of borders enclosing the nation, recently illustrated by the analyses of Fassin (2011), Parizot (2008), and Yuval-Davis et al. (2017), among many others.

In this book, boundaries point to the group (class) identifications among socioeconomic strata in Kilis. To set it more clearly, this book valorizes Barth's original question about how the group identifications could be maintained despite their boundaries being transgressed. It shows how the tensions of old/new wealth and upper strata/peasantry are constantly negotiated through marriages and other forms of alliances across borders and boundaries.

\section{Social mobility}

I draw on an oral history approach in order to underline my methodological premises related to social mobility. Social mobility can be defined as the movement up and down the stratification (Kerbo, 2006). Border historians turn to oral history in order to "reconstruct the historical self-images and perceptions of social groups in the borderland and the impact of these on people's political, economic, and cultural behavior" (Baud and van Schendel, 1997, p. 242). I adopt oral history as a theoretical perspective to inform social stratification analyses with particular emphasis on social mobility, which is brilliantly illustrated by the works of oral historians Daniel Bertaux and Paul Thompson (1997). They argue that narrative approach exceeds the often-preferred survey method in social mobility studies by revealing the crucial importance of local context. While social mobility processes in Kilis town could be analyzed in conformity with regular patterns of mobility, they critically diverge in terms of subjective perceptions and evaluations and local structures of opportunities. Narrativity adds great power in explaining the reproduction, transformation, emergence, or disappearance of class and status in border zones, where a fast buck could be as easily spent as it is earned.

The overly changing nature of borders and border policies differentially allowing and hindering the border-crossings generate a context of unequal power 


\section{Introduction}

relations in which the social hierarchies of class, status, and prestige fluctuate. Arbitrary border policies allocate unequal risks to various strata but they normalize them as consequences of living at the border (Cunningham and Heyman, 2004, p. 294). Therefore, this book adopts an analysis of social stratification structure with the aim of determining the parameters of social mobility rather than describing the class positions and identities. An oral history approach to social mobility helps to unravel family histories, which are "such extraordinarily rich sources of hard information directly relating to the construction of social trajectories [of social mobility]" (Bertaux, 1989, p. 85). According to Bertaux, the key concept to the analysis of social mobility is transmission.

An oral history approach relies on case histories of families in order to trace the social status as construed as a property of family groups, which is transmitted among generations (Bertaux and Bertaux-Wiame, 1997). Rather than individuals, parent-offspring relationships are inquired. Bertaux-Wiame and Thompson (1997) define social mobility in terms of regular patterns such as intergenerational occupational transmission, the role of marriage, access to education and housing as cultural capital. In the case of Kilis, the familial histories particularly account for the local notables that depends on their patrimonial wealth as well as paternalistic relationships of agrarian production. However, they also shed light on what ways new wealth as well as the lower strata diverge from expected social trajectories of class reproduction, i.e. in cases that the occupation is not transmitted between generations. While these patterns constitute the vertical mobility paths of families by transmitting their economic and cultural capital to their offspring, I also add the conversion of capital held in one form to another as an aspect of horizontal mobility.

Conversion of one type of capital into another, Bourdieu argues, occurs only if the latter is "more profitable or more legitimate in the current state of instruments of reproduction" (Bourdieu, 1998, p. 277). For Bourdieu, there are four types of capital, including economic, cultural, social, and symbolic. Yet he considers the economic and cultural capital possessed by individuals as the most important. Bourdieu emphasizes that cultural capital is heritable and critical to the reproduction of social standing among individuals. This type of mobility, usually neglected by other models of social mobility, can also shed light on various conflicts between various groups among social strata (Weininger, 2005).

\section{Social stratification}

A transdisciplinary study of in/exclusion in Kilis town needs to be framed within the context of local power and inequality structures that remain latent in border zones. Although the cartographic mapping makes the territorial boundaries appear as crossing deserted plateaus and mountains, wide and barren fields without human trace, borders are not demarcated on blank space. The demarcation of border shifts the social stratification among inhabitants and alters the forms of identification.

Social stratification refers to a hierarchy and inequality of ranking among social groups in the society. It incorporates institutional processes that create 
these hierarchies and inequalities as well as mobility mechanisms that shift them. Classification among social groups can be done according to a set of categories: namely, the degree of inequality, rigidity of the stratification system, ascriptive traits and degree of status crystallization (Grusky, 1994). A Marxian tradition, informed by the theories of Marx as well as Weber, has long produced numerous work to bring the class and status groups within a single analytical framework. Bourdieu's reproduction theory (1984) has made a great leap forward to straddle the division between class and status, by incorporating the notion of distinction and taste and defines classes on the basis of their internalized dispositions - or tastes - rather than objective conditions of existence. While this book adopts Bourdieu's approach to social mobility in terms of reproduction and conversion, it nevertheless embraces the concept of 'strata' as a key concept of analysis in order to address the unresolved division between class and status groupings.

Studying the demarcation of Kilis border town has a theoretical backdrop informed by the Ottoman social stratification system. The latter lies at the roots of class structure of modern Turkey. One approach in the Ottoman historiography conceptualizes the Ottoman social stratification as Asiatic, with peculiar ascription and achievement criteria than those existing in Western Europe. This line of thought conceives the Asiatism as an intermediate formation in the transition of advanced agrarian society (Grusky, 1994, p. 9). For example, Şerif Mardin (1967) is a proponent of this approach, tracing the origins of contemporary class structure in Turkey back to the Ottoman social order. Mardin conceptualizes the Ottoman social order in a dichotomy of the ruling class and the ruled class, the latter mainly being the peasantry. According to him, the most important shift in the Ottoman stratification structure had been the Land Code of 1858 allowing private proprietorship of the state lands. The private proprietorship of land had led to the emergence of a new class of landowners as the ruling class in the provincial Ottoman. An important aspect of Ottoman social stratification was its rigid nature as expressed by the ruling class' concern for "everyone keeping his proper place" (Mardin, 1967, p. 129).

Mardin argues that the nascent Turkish regime has largely preserved the Ottoman social stratification structure split by a historical dichotomy between the ruling and the ruled, as well as intra-group conflict among the ruling elite. The provincial rulers in the Ottoman Empire are regarded by the Ottoman historiography as "notables" playing a role as intermediaries between central authority and the local population (e.g., Hourani, 1968). For these scholars, the feudal relationships, such as large landholding, which are inherited by the Republican State, complicate the analysis of social stratification structure in terms of capitalist classes.

A second line of thought in Ottoman historiography explores the unfolding of Ottoman history on the basis of the mode of incorporation of the Ottoman Empire into the capitalist world economy: peripheralization thesis (Keyder, 1991). This approach, in turn, aims to define social classes in terms of production relationships and ownership of the means of production. The two lines do not only diverge in defining the mode of production (Asiatic or peripheral capitalist) but also contend each other in the definition of social stratification structure in the Ottoman order. Khoury tries to bridge the two lines by discussing the definition of local notables 


\section{Introduction}

as a class with respect to property or its relationship to the means of production as well as to the social position of its constituents (Khoury, 1990, p. 219). He discusses the notables as a class per se, but also as a "class in formation" by emphasizing the significance of the social standing together with the ownership of the means of production and the patronage relationships, which put to their disposal a wider range of benefits and services than the landownership would. I adopt Khoury's definition in conceptualizing the notables as a social class to unearth their social reproduction and mobility strategies, which do not attract enough interest in the Turkish scholarship.

My discussion about the inner social stratification in Kilis town does not go against the grain of the Turkish social stratification debate but rather engages in a conversation with it. My analysis critically adopts the peripheralization thesis and dwells on the agrarian question that occupied the attention of Ottoman historiography for a long time. Briefly, this thesis argues that the petty-commodity production prevailed among the peasants after the World War II together with the decline of large landholding and sharecropping. I underline the role of local notables, the status of peasantry, and shifting relationships on land tenure as well as patronage in the transition to the Republican regime. I pay particular attention to trace the shift of 'traditional' relationships based on reciprocity and kinship to scrutinize the ways in which these relationships continue to be effective, informing new power and inequality structures in market economy.

I contribute to the debate by shedding light on the mechanisms of illicit wealth generation and redistribution, as well as their normalization embedded in everyday transactions and exchanges, as part of social reproduction and mobility strategies. I demonstrate that the wealth generation through illicit means underpins the vested interests of traditional landed notables and prevents the peasantry from gaining independence. This book elaborates on the historical evolution of underlying mechanisms with the transition from the late Ottoman to the Republican era. These mechanisms have recently come on the radar within the framework of post-1980 trade liberalization and neoliberal governance. Therefore, the rise of new wealth, capitalizing on the post-1980 trade liberalization policies, has mainly attracted scholarly attention as a post-1980 phenomenon (Bali, 2007). However, this book points to the ascendance of new wealth between the 1960s and 1980s. It also shows how new relations of dependency are established between the ascendant wealth and the peasant poor. The analysis of social mobility processes, moving beyond methodological territorialism, captures the sub-national and transnational dynamics of wealth generation.

\section{Presentation of chapters}

I elaborate further on the theoretical background of the above-mentioned conceptual sources in Chapter 1 in order to explore the inner stratification and change in Kilis border town. I give an account of seemingly divergent theoretical threads on border studies: first, the conception of borders as liminal spaces and second, the conception of borders as state margins. I evaluate these threads on the basis of 
their strength and weaknesses in order to redress an interdisciplinary approach to the study of borderlands. Lastly, I review the Turkish literature on border in order to highlight the main themes and questions.

The objective of the three following parts is to present the empirical analysis of social mobility strategies among three strata, each being devoted a separate part. In Chapters 2 and 3, it is argued that subjective perceptions and evaluations of traditional notables about the shift in their status as old wealth have culminated in their experience of falling from grace since the 1960s. By carrying out a discussion about whether the local notables could be considered as early capitalists, these chapters indicate that these families could benefit from new opportunities in the circulation of goods and gold as the border transit regime allowed them to access their landed estates and the trade markets in northern Syria and yield an economic accumulation. Thus, they show that local notables had to embrace illegal means of economic accumulation and accept what was once disgraceful for them in order to reproduce their social standing, while this process irrevocably undermined the social capital that traditional landed notables relied on to distinguish themselves from trade notables, the latter being more adept in seizing new opportunities of illicit trade.

Chapters 4 and 5 focus on the growth of the shadow economy along Kilis border and explore the social and economic conditions of the rise of new wealth since the 1960s. They detail how the town dwellers took benefit of the protective measures during the import-substituting industrialization period of 1960-1980 by reckoning rents to the illegal entry of consumer goods as well as gold and foreign currency. Chapter 5 shows that the illegal trade of gold as well as consumer goods promoted upward mobility by undermining structural constraints of social stratification and shifted the social and urban landscape of the town by embedding the local economy into national and transnational shadow networks.

The third section is the last one devoted to the empirical analysis of the ways in which rural and urban poor turned into border labourers and normalized their engagements in illegal trade. Chapter 6 highlights the historical conditions in which the rural poor emancipated themselves from the paternal relationships of patronage established with large landholders, which, yet, were quickly replaced by large-scale entrepreneurs that drew on traditional power structures based on land tenure and kinship. It argues that illegal trade at the border gave rise to a border economy, with the mining of the border from the mid-1950s. Then it explores how the cross-border trade regulations officially introduced in Kilis border in the mid-1990s permitted the town dwellers to yield differential profits and reckon upon a semi-legal small-scale trade. Chapter 7 demonstrates that the rural and urban poor, in the absence of patronage by large-scale entrepreneurs, are increasingly exposed to the dangers of criminalization and being unable to pay criminal fines, dangers of growing economic indebtedness. It also points to the ways in which the poor historically relied on kinship relations to normalize their exchange practices deemed illegal by local authorities.

The conclusion highlights the main findings by drawing on the overriding debates of the book with particular emphasis on social trajectories of socioeconomic strata and their stories of social mobility and belonging. Finally, the 
Epilogue to this book offers a snapshot of the post-conflict situation in this borderland with a focus on the demographic change, local hospitality towards refugees, emergence of a humanitarian-military nexus and shifts in the local labour market after the refugee arrivals, as well as the ascendance of a war economy and new trade geographies in the broader region.

\section{Notes}

1 Bilad al-Sham historically refers to the geographical region, which is also known as the Levant or Greater Syria.

2 The governmental policy stipulates the temporary protection of Syrian refugees and does not provide the right to asylum. This topic will be revisited in the Epilogue.

3 For instance, according to Ekrem, a local historian, the Turkification of Kilis region was due to a Karahanl prince as he defeated the Byzantine dominion and the settlement of his retinue of Turcoman tribes, while the conversion of the locals to Islam happened under the Ottoman rule after the conquest of these lands with the Mercidabik War in 1516. But, Aydin (2011) argues that the Turcoman tribal identity was originally quite dissimilar to the modern Turkish ethnicity.

\section{References}

Altuğ, S. (2002) Between Colonial and National Dominations: Antioch under the French Mandate (1920-1939), unpublished MA thesis, Boğaziçi University, Istanbul.

Altuğ S. and White B. T. (2009) "Frontières et pouvoir d'État. La frontière turco-syrienne dans les années 1920 et 1930", Vingtième siècle, 103: 91-104.

Aras, B. and Polat, R. K. (2008) "From Conflict to Cooperation: Desecuritization of Turkey's Relations with Syria and Iran", Security Dialogue, 39(5): 475-495.

Aydın, S. (2011) "Baraklar: Antep'in İskan Halkı”, pp. 155-234 in M. Nuri Gültekin (ed.), Ta Ezelden Taşkındır: Antep, İstanbul: İletişim.

Bali, N. R. (2007) Tarz-ı Hayat tan Life Style’a:Yeni Seçkinler, Yeni Mekanlar,Yeni Yaşamlar, Istanbul: İletişim Yayınları.

Barth, F. (1969) Ethnic Groups and Boundaries: The Social Organization of Culture Difference, Boston: Little, Brown.

Baş, A. (2012) “1957 Suriye Krizi ve Türkiye”, Historical Studies, 4(1): 89-109.

Baud, M. and van Schendel, W. (1997) "Toward a Comparative History of Borderlands", Journal of World History, 8(2): 211-242.

Bertaux D. and Bertaux-Wiame, I. (1997) "Heritage and Its Lineage: A Case History of Transmission and Social Mobility over Five Generations", pp. 62-97 in I. BertauxWiame and P. Thompson (ed.), Pathways to Social Class: A Qualitative Approach to Social Mobility, Oxford: Clarendon Press.

Bertaux, D. (1989) "From Methodological Monopoly to Pluralism in the Sociology of Social Mobility", The Sociological Review, 37(1): 73-92.

Bertaux-Wiame, I. and Paul T. (1997) "The Familial Meaning of Housing in Social Rootedness and Mobility: Britain and France”, pp. 124-182 in I. Bertaux-Wiame and P. Thompson (eds.), Pathways to Social Class: A Qualitative Approach to Social Mobility, Oxford: Clarendon Press.

Biner, Ö. Z. (2010) "Acts of Defacement, Memory of Loss: Ghostly Effects of the 'Armenian Crisis' in Mardin, Southeastern Turkey”, History \& Memory, 22(2): 68-94.

Bourdieu, P. (1984) Distinction: A Social Critique to the Judgment of Taste, Cambridge: Harvard University Press. 


\section{Introduction}

Altuğ, S . (2002) Between Colonial and National Dominations: Antioch under the French Mandate (1920-1939), unpublished MA thesis, Boğaziçi University, Istanbul.

Altuğ S . and White B . T. (2009) "Frontières et pouvoir d'État. La frontière turco-syrienne dans les années 1920 et 1930", Vingtième siècle, 103: 91-104.

Aras, B. and Polat, R. K. (2008) "From Conflict to Cooperation: Desecuritization of Turkey's Relations with Syria and Iran", Security Dialogue, 39(5): 475-495.

Aydın, S . (2011) "Baraklar: Antep'in İskan Halkı", pp. 155-234 in M. Nuri Gültekin (ed.), Ta

Ezelden Taşkındır: Antep, İstanbul: İletişim.

Bali, N. R. (2007) Tarz-ı Hayat'tan Life Style'a:Yeni Seçkinler, Yeni Mekanlar,Yeni Yaşamlar, Istanbul: İletişim Yayınları.

Barth, F. (1969) Ethnic Groups and Boundaries: The Social Organization of Culture Difference, Boston: Little, Brown.

Baş, A . (2012) "1957 Suriye Krizi ve Türkiye", Historical Studies, 4(1): 89-109.

Baud, M. and van Schendel, W. (1997) "Toward a Comparative History of Borderlands", Journal of World History, 8(2): 211-242.

Bertaux D. and Bertaux-Wiame, I. (1997) "Heritage and Its Lineage: A Case History of Transmission and Social Mobility over Five Generations", pp. 62-97 in I. Bertaux-Wiame and P. Thompson (ed.), Pathways to Social Class: A Qualitative Approach to Social Mobility, Oxford: Clarendon Press.

Bertaux, D. (1989) "From Methodological Monopoly to Pluralism in the Sociology of Social Mobility", The Sociological Review, 37(1): 73-92.

Bertaux-Wiame, I. and Paul T. (1997) "The Familial Meaning of Housing in Social Rootedness and Mobility: Britain and France", pp. 124-182 in I. Bertaux-Wiame and P. Thompson (eds.), Pathways to Social Class: A Qualitative Approach to Social Mobility, Oxford: Clarendon Press. Biner, Ö . Z. (2010) "Acts of Defacement, Memory of Loss: Ghostly Effects of the 'Armenian Crisis' in Mardin, Southeastern Turkey", History \& Memory, 22(2): 68-94.

Bourdieu, P. (1984) Distinction: A Social Critique to the Judgment of Taste, Cambridge: Harvard University Press.

Bourdieu, P. (1998) "Forms of Power and Their Reproduction", pp. 263-299 in The State Nobility: Elite Schools in the Field of Power, Oxford: Polity Press.

Bruner, E. M. (1986) "Ethnography as Narrative", pp. 139-158 in Victor M. Turner and E. M. Bruner (eds.), The Anthropology of Experience, University of Illinois Press.

Buursink, J. (2001) "The Binational Reality of Border-Crossing Cities", GeoJournal, 54: 7-19. Canefe, N. (2002) "Turkish Nationalism and Ethno-Symbolic Analysis: The Rules of Exception", Nations and Nationalism, 8(2): 133-155.

Clifford, J. and Marcus, G. E. (1986) Writing Culture: The Poetics and Politics of Ethnography, University of California Press.

Cunningham, H. and Heyman, J. (2004) "Introduction: Mobilities and Enclosures at Borders", Identities: Global Studies in Culture and Power, 11: 289-302.

Di Leonardo , M. (1987) "Oral History as Ethnographic Encounter", The Oral History Review, 15(1): 1-20.

Doevenspeck, M. (2011) "Constructing the Border from Below: Narratives from the CongoleseRwandan State Boundary", Political Geography, 30: 129-142.

Doğruel, F . (2013) "An Authentic Experience of 'Multiculturalism' At the Border City of Antakya", Çağdaş Türkiye Tarihi Araştırmaları Dergisi/Journal of Modern Turkish History Studies XIII/26(Bahar/Spring): 273-295.

Donnan, H. and Wilson, T. M. (1999) Borders: Frontiers of Identity, Nation and State, Oxford: Berg.

Fassin, D. (2011) "Policing Borders, Producing Boundaries: The Governmentality of Immigration in Dark Times", Annual Review of Anthropology, 40: 213-226.

Flynn, D. K. (1997) "'We Are the Border': Identity, Exchange, and the State Along the BeninNigeria Border", American Ethnologist, 24(2): 311-330.

Grusky, D. B. (1994) "The Contours of Social Stratification”, pp. 3-35 in David B. Grusky (ed.), Social Stratification: Class, Race, and Gender in Sociological Perspective, Boulder: Westview Press. 
Güçlü, Y . (2006) "The Controversy over the Delimitation of the Turco-Syrian Frontier in the Period between the Two World Wars", Middle Eastern Studies, 42(4): 641-657.

Hourani, A. (1968) "Ottoman Reform and the Politics of Notables", pp. 41-68 in W. R. Polk and R. L. Chambers (eds.), Beginnings of Modernization in the Middle East, University of Chicago Press.

Kasaba, R. (2004) "Do States Always Favor Stasis? Changing Status of Tribes in the Ottoman Empire", pp. 27-48 in J. Migdal (ed.), Boundaries and Belonging, Cambridge: Cambridge University Press.

Kerbo, H. R. (2006) "Social Stratification", pp. 228-236 in C. D. Bryant and D. L. Peck (eds.), 21st Century Sociology: A Reference Handbook, Thousand Oaks, CA and London: Sage Publications.

Keyder, Ç . (1991) "Introduction: Large-Scale Commercial Agriculture in the Ottoman Empire?", pp. 1-16 in Ç. Keyder and F. Tabak (eds.), Landholding and Commercial Agriculture in the Middle East, Albany, NY: State University of New York.

Khoury, P. S. (1990) "The Urban Notables Paradigm Revisited", Revue du monde musulman et de la Méditerranée, 55-56: 215-230.

Kibritoğlu, M . \& Çelebioğlu, R . (2012) "Başbakan Erdoğan'dan Esad'a sınırdan gözdağı", Hürriyet, 6 May . Available at http://www.hurriyet.com.tr/gundem/basbakan-erdogandan-esadasinirdan-gozdagi-20496557 [accessed at 7.5.2018 ]

Köknar, A . (2004) "Turkey Moves Forward to Demine Upper Mesopotamia", Journal of ERW and Mine Action, 8(2): 54-55.

Mardin, Ş . (1967) "Historical Determinants of Stratification: Social Class and Class Consciousness in the Ottoman Empire", Siyasal Bilgiler Fakültesi Dergisi, 22(4): 111-142.

Martinez, O. (1994) Border People: Life and Society in the U.S.-Mexico Borderlands, University of Arizona Press.

Migdal, J. (2004) "Mental Maps and Virtual Checkpoints: Struggles to Construct and Maintain

State and Social Boundaries", pp. 3-26 in J. Migdal (ed.), Boundaries and Belonging: States and Societies in the Struggle to Shape Identities and Local Practices, Cambridge University Press.

Newman, D. (2003) "On Borders and Power: A Theoretical Framework", Journal of Borderland Studies, 18(1): 13-25.

Olson, R. (1997) "Turkey-Syria Relations since the Gulf War: Kurds and Water", Middle East Policy, 5(2): 168-193.

Özgen, N . (2010) "Mayınlı Arazilerin Temizlenmesi Üzerine”, Almanak, Istanbul: SAV. Paasi, A. (2011) "A 'Border Theory': An Unattainable Dream or a Realistic Aim for Border Scholars?", pp. 11-31 in D. Wastl-Walter (ed.), A Research Companion to Border Studies, Aldershot: Ashgate.

Paasi, A. (2003) "Boundaries in a Globalizing World", pp. 462-472 in K. Anderson , M. Domosh , S. Pile and N. Thrift (eds.), Handbook of Cultural Geography, London: Sage Publications.

Parizot, C. (2008) "Crossing Borders, Retaining Boundaries: Kin-nections of Negev Bedouin in Gaza, West Bank, and Jordan", pp. 58-84 in S. Hanafi (ed.), Crossing Borders, Shifting Boundaries: Palestinian Dilemmas, Cairo: American University in Cairo Press.

Pelkmans, M. (2006) Defending the Border: Identity, Religion, and Modernity in the Republic of Georgia (Culture and Society after Socialism), University of Cornell Press.

Rapport, N. J. (2000) "The Narrative as Fieldwork Technique: Processual Ethnography for a World in Motion", pp. 71-95 in V. Amit (ed.), Constructing the Field: Ethnographic Fieldwork in The Contemporary World, London, Routledge.

Soyudoğan, M . (2005) Tribal Banditry in Ottoman Ayntab (1690-1730), unpublished MA thesis, Bilkent University.

Strassoldo, R. (1980) "Centre-Periphery and System-Boundary: Culturological Perspectives", pp. 27-61 in J. Gottman (ed.), Centre and Periphery: Spatial Variations in Politics, London: Sage Publications.

TBMM (1922) Gizli Celse Tutanakları (Minutes of Closed Session of TGNA) , Volume 3, Legislative Year III , 15.1.1922.

Thompson, P. (1998) "The Voice of the Past: Oral History", in R. Perks and A. Thomson (eds.), The Oral History Reader, London: Routledge.

Tuncer-Gürkaş, E . (2014) "Belirsizlik mıntıkası ya da daimi istisna hali olarak sınır: Güneydoğu kampı içinde Mardin-Kızıltepe ikiz kampları”, Toplum ve Bilim, 131: 219-235. 
van Schendel, W. (2005) "Studying Borderlands", pp. 1-24 in The Bengal Borderlands: Beyond State and Nation in South Asia, London: Anthem Press.

Vila, P. (1997) "Narrative Identities: The Employment of the Mexican on the U.S.-Mexican Border", Sociological Quarterly, 38(1): 147-194.

Vila, P. (2000) Crossing Borders, Reinforcing Borders: Social Categories, Metaphors, and Narrative Identities on the U.S.-Mexico Frontier, Austin: University of Texas Press.

Vila, P. (2003) "Introduction: Border Ethnographies", pp. ix-xxxv in Pablo Vila (ed.),

Ethnography at the Border (Cultural Studies of the Americas), University of Minnesota Press.

Weininger, E. B. (2005) "Chapter 4: Foundations of Pierre Bourdieu's Social Class", pp.

119-149 in E. O. Wright (ed.), Approaches to Class Analysis, Cambridge University Press.

Wilson, T. and Donnan, H. (1998) Border Identities: Nation and State at International Frontiers, Cambridge University Press.

Yuval-Davis, N. , Wemyss G. and Cassidy K. (2017) "Introduction to the Special Issue:

Racialized Bordering Discourses on European Roma", Ethnic and Racial Studies, 40(7):

1047-1057.

\section{Exploring community and change from border perspective}

Abraham, I. and van Schendel, W (2005) "Introduction: The Making of Illicitness", pp. 1-37 in

W. van Schendel and I. Abraham (eds.), Illicit Flows and Criminal Things: States, Borders, and the Other Side of Globalization, Bloomington: Indiana University Press.

Akyüz, L. (2013) Ethnicity and Gender Dynamics of Living in Borderlands: The Case of HopaTurkey, unpublished PhD dissertation, METU, Ankara.

Akyüz, L. (2014) "Liminal Alanlar olarak Sınırlar: Türkiye-Gürcistan Sınırında Ekonomik Yaşam ve Etnik Kimliklerin Sınır Deneyimleri", Toplum ve Bilim, 131: 84-103.

Alonso, A. M. (2005) "Sovereignty, the Spatial Politics of Security, and Gender: Looking North and South from the US-Mexico Border", pp. 27-52 in C. Krohn-Hansen and K. G. Nustad (eds.), State Formation: Anthropological Perspectives, London; Ann Arbor, MI: Pluto Press. Altuğ, S . and White, B . T. (2009) "Frontières et pouvoir d'État. La frontière turco-syrienne dans les années 1920 et 1930", Vingtième siècle, 103: 91-104.

Alvarez, R. (1995) "The Mexico-U.S. Border: The Making of an Anthropology of Borderlands", Annual Review of Anthropology, 24: 447-470.

Andreas, P. (2000) Border Games: Policing the US-Mexico Divide, Ithaca: Cornell University Press.

Andreas, P. (2011) "Illicit Globalization: Myths, Misconceptions, and Historical Lessons", Political Science Quarterly, 126(3): 403-425.

Appadurai, A. (1990) "Disjuncture and Difference in the Global Culture Economy", Theory, Culture, and Society, 7: 295-310.

Asiwaju A. I . (1994) "Borders and Borderlands as Linchpins for Regional Integration in Africa: Lessons of the European Experience", pp. 57-75 in C. H. Schofield (ed.), World Boundaries Vol. 1 (Global Boundaries), London: Routledge.

Ateş, S . (2011) "Bones of Contention: Corpse Traffic and Ottoman-Iranian Rivalry in Nineteenth-Century Iraq", Comparative Studies of South Asia, Africa and the Middle East, 30(3): 521-532.

Baban, F. , Ilcan, S. and Rygiel, K. (2017) "Playing Border Politics with Urban Syrian Refugees: Legal Ambiguities, Insecurities, and Humanitarian Assistance in Turkey", Movements: Journal for Critical Migration and Border Regime Studies, 3(2): 79-100.

Baud, M. and van Schendel, W. (1997) "Toward a Comparative History of Borderlands", Journal of World History, 8(2): 211-242.

Beller-Hann, I . and Hann, C . (1998) "Markets, Modernity and Morality in North-East Turkey", pp. 237-262 in T. Wilson and H. Donnan (eds.), Border Identities: Nation and State at International Frontiers, Cambridge: Cambridge University Press.

Brandell, I. (2006) "Introduction", I. Brandell (ed.), State Frontiers: Borders and Boundaries in the Middle East, London, New York: I.B. Tauris.

Castells, M. (1996) The Rise of the Network Society, The Information Age: Economy, Society and Culture, Vol. I. Cambridge, MA; Oxford: Blackwell. 
Cheater, A. P. (1998) "Transcending the State? Gender and Borderline Constructions of Citizenship in Zimbabwe", pp. 191-214 in T. Wilson and D. Hastings (eds.), Border Identities: Nation and State at International Frontiers, Cambridge: Cambridge University Press.

Cizre, Ü . (2001) "Turkey's Kurdish Problem: Borders, Identity and Hegemony", pp. 222-250 in B. O'Leary , I. S. Lustick and T. Callaghy (eds.), Rightsizing the State: The Politics of Moving Borders, Oxford; New York: Oxford University Press.

Cole, J. W. and Wolf, E. R. (1974) The Hidden Frontier: Ecology and Ethnicity in an Alpine Valley, New York: Academic Press.

Curtis J. R. and Arreola, D. D. (1991) "Zonas de Tolerancia on the Northern Mexican Border", Geographical Review, 81(3): 333-346.

Das, V. and Poole, D. (2004) "State and Its Margin: Comparative Ethnographies", pp. 3-34 in V. Das and D. Poole (eds.), Anthropology in the Margins of the State, Santa Fe: School of American Research Press.

Doğruel, F . (2013) "An Authentic Experience of 'Multiculturalism' at the Border City of Antakya", Çağdaş Türkiye Tarihi Araştırmaları Dergisi/Journal of Modern Turkish History Studies XIII/26 (Bahar/Spring), 273-295.

Donnan, H. and Wilson, T. M. (1999) Borders: Frontiers of Identity, Nation and State, Oxford: Berg.

Dragojlovic, A. (2008) "Reframing the Nation: Migration, Borders and Belonging", The Asia Pacific Journal of Anthropology, 9(4): 279-284.

Galemba R. (2008) "Informal and Illicit Entrepreneurs: Fighting for a Place in the Neoliberal Economic Order", Anthropology of Work Review, 29(2): 19-25.

Galemba, R. (2012) '“Corn is Food, Not Contraband': The Right to 'Free Trade' at the Mexico-Guatemala Border", American Ethnologist, 39(4): 716-734.

Galemba, R. (2013) "Illegality and Invisibility at Margins and Borders", Political and Legal Anthropology Review, 36(2): 274-285.

Gavrilis, G. (2008) "The Greek-Ottoman Boundary as Institution, Locality, and Process 1832-1882", American Behavioral Scientist, 51(10): 1512-1537.

Genç, D . (2015) "An Analysis of Turkey's Bordering Processes: Why and Against Whom?", Turkish Studies, 16(4): 527-533.

Grimson, A. (2006) "Cultures are More Hybrid than Identifications: A Dialogue on Borders from the Southern Cone", Latino Studies, 4: 96-119.

Gupta, A. (1995) "Blurred Boundaries: The Discourse of Corruption, the Culture of Politics, and the Imagined State", American Ethnologist, 22(2): 375-402.

Gupta, A. and Ferguson, J. (1992) "Beyond 'Culture': Space, Identity, and the Politics of Difference", Cultural Anthropology, 7(1): 6-23.

Heck, G. and Hess, S. (2017) "Tracing the Effects of the EU-Turkey Deal: The Momentum of the Multi-layered Turkish Border Regime", Movements: Journal for Critical Migration and Border Regime Studies, 3(2): 35-56.

Heyman, J. and Campbell, H. (2007a) "Slantwise: Beyond Domination and Resistance on the Border", Journal of Contemporary Ethnography, 36: 3-30.

Heyman, J. and Campbell, H. (2007b) "Corruption in the U.S. Borderlands with Mexico: The 'Purity' of Society and the 'Perversity' of Borders", pp. 191-217 in M. Nuijten and G.Anders , (eds.), Corruption and the Secret of Law: A Legal Anthropological Perspective, Aldershot: Ashgate.

Heyman, J. and Campbell, H. (2009) "The Anthropology of Global Flows: A Critical Reading of Appadurai's 'Disjuncture and Difference in the Global Cultural Economy'”, Anthropological Theory, 9(2): 131-148.

Heyman, J. and Cunningham, H. (2004) "Introduction: Mobilities and Enclosures at Borders", Identities: Global Studies in Culture and Power, 11: 289-302.

Hill, S. (2003) "Metaphoric Enrichment and Material Poverty: The Making of 'Colonias'”, pp. 141-167 in P. Vila (ed.), Ethnography at the Border, Minneapolis: University of Minneapolis Press.

İçduygu, A . and Kaygusuz, Ö . (2004) "The Politics of Citizenship by Drawing Borders: Foreign Policy and the Construction of National Citizenship Identity in Turkey", Middle Eastern Studies, 40(6): 26-50.

İçduygu, A. and Toktaş, Ş . (2002) "How Do Smuggling and Trafficking Operate via Irregular Border Crossings in the Middle East?", International Migration, 40(6): 25-52. 
Kaşlı, Z . (2014) "Kimine duvar kimine komşu kapısı: Türkiye-Yunanistan sınırının seçici geçirgenliği", Toplum ve Bilim, 131: 44-68.

Kaşlı, Z . (2017) "A Tale of Two Cities: Multiple Practices of Bordering and Degrees of 'Transit' in and through Turkey", Journal of Refugee Studies, 29(4): 528-548.

Kaşlı, Z . and Parla, A . (2009) "Broken Lines of II/Legality and the Reproduction of State Sovereignty: The Impact of Visa Policies on Immigrants to Turkey from Bulgaria", Alternatives, 34(2): 203-227.

Kolossov, V. (2005) "Border Studies: Changing Perspectives and Theoretical Approaches", Geopolitics, 10(4): 606-632.

Marcus, E. G. and Clifford, J. (1986) Writing Culture: The Poetics and Politics of Ethnography, Berkeley: University of California Press.

Megoran, N. (2006) "For Ethnography in Political Geography: Experiencing and Re-Imagining Ferghana Valley Boundary Closures", Political Geography, 25: 622-640.

Navaro-Yashin, Y. (2003) “'Life is Dead Here': Sensing the Political in 'No Man's Land'”, Anthropological Theory, 3(1): 107-125.

Newman, D. (2003) "On Borders and Power: A Theoretical Framework", Journal of Borderland Studies, 18(1): 13-25.

Nordstrom, C. (2000) "Shadows and Sovereigns", Theory, Culture and Society, 17(4): 35-54. Nordstrom, C. (2001) "Out of Shadows", pp. 216-239 in M. Barnett et al. (eds.), Intervention and Transnationalism in Africa: Global-Local Networks of Power, Cambridge: Cambridge University Press.

Nordstrom, C. (2011) '“Extra-Legality in the Middle', Illicit Crossings: Smuggling, Migration, Contraband", Middle East Report 261(41): 10-13.

Nugent, P. (2012) "Border Towns and Cities in Comparative Perspective: Barriers, Flows and Governance", pp. 557-572 in T. Wilson and H. Donnan (eds.), A Companion to Border Studies (Blackwell Companion to Anthropology), Oxford: Blackwell.

Obeid, M. (2010) "Searching for the 'Ideal Face of the State' in a Lebanese Border Town", Journal of the Royal Anthropological Institute, 16(2): 330-346.

Özcan, Ö . (2014) "Yüksekova'da Sınır Deneyimleri: Bir "Sınır Kaçakçılığı" Hikâyesi ve Barış Süreci", Toplum ve Bilim, 131: 162-185.

Özgen, N . (2004) "Sınır Kasabaları Sosyolojisi", unpublished report for research project sponsored by TUBITAK and Ege Üniversity Bilim-Teknoloji Uygulama ve Araştırma Merkezi (EBILTEM), İzmir. Retrieved 13 September 2014 from http://neseozgen.net/wpcontent/uploads/26.pdf.

Özgen, N . (2006) "Vatanın Çerçevesi Olarak Sınırlar: Haco Ağa ve Alakamış Katliamı Örneği”" Tiroj, Eylül-Ekim.

Özgen, N . (2007a) "Devlet, Sınır, Aşiret: Aşiretin Etnik Bir Kimlik Olarak Yeniden İnşası", Toplum ve Bilim, 108: 239-261.

Özgen, N . (2007b) “Öteki'nin Kadını: Beden ve Milliyetçi Politikalar”, Türkiye'de Feminist

Yaklaşımlar, no. 2. Retrieved 13 September 2014 from www.feministyaklasimlar.org/sayi-02subat-2007/otekinin-kadini-beden-ve-milliyetci-politikalar/.

Paasi, A. (2011) "A 'Border Theory': An Unattainable Dream or a Realistic Aim for Border Scholars?" pp. 11-31 in D. Wastl-Walter (ed.), A Research Companion to Border Studies, Aldershot: Ashgate.

Parizot, C. (2008) "Crossing Borders, Retaining Boundaries: Kin-nections of Negev Bedouin in Gaza, West Bank, and Jordan", pp. 58-84 in S. Hanafi (ed.), Crossing Borders, Shifting Boundaries: Palestinian Dilemmas, Cairo: American University in Cairo Press.

Pelkmans, M. (2006) Defending the Border: Identity, Religion, and Modernity in the Republic of Georgia (Culture and Society after Socialism), Ithaca, NY: University of Cornell Press.

Reeves, M. (2007) "Unstable Objects: Corpses, Checkpoints and 'Chessboard Borders in the Ferghana Valley", Anthropology of East Europe Review, 25(1): 72-84.

Roitman, J. (1990) "The Politics of Informal Markets in Sub-Saharan Africa", The Journal of Modern African Studies, 28(4): 671-696.

Roitman, J. (2004a) "Introduction", pp. 1-22 in Fiscal Disobedience: An Anthropology of Economic Regulation in Central Africa, Princeton, NJ: Princeton University Press.

Roitman, J. (2004b) "Productivity in the Margins: The Reconstitution of State Power in the Chad Basin", pp. 191-224 in D. Poole and V. Das (eds.), Anthropology at the Margins of the State, Santa Fe: School of American Research Press. 
Roitman, J. (2004c) "The Garrison-Entrepôt: A Mode of Governing in the Chad Basin", pp. 417-436 in A. Ong and S. J. Collier (eds.), Global Assemblages: Technology, Politics, and Ethics as Anthropological Problems, Hoboken, NJ: Wiley-Blackwell.

Roitman, J. (2006) "The Ethics of Illegality in the Chad Basin", pp. 247-272 in J. Comaroff and J. Comaroff (eds.), Law and Disorder in the Postcolony, Chicago: University of Chicago Press. Roitman, J. (2007) "The Right to Tax: Economic Citizenship in the Chad Basin", Citizenship Studies, 11(2): 187-209.

Sahlins, P. (1998) "State Formation and National Identity in the Catalan Borderlands during the Eighteen and Nineteenth Centuries", pp. 31-61 in T. M. Wilson and H. Donnan (eds.), Border Identities: Nation and State at International Frontiers, Cambridge: Cambridge University Press. Staudt, K. and David, S. (1998) "The View from the Frontier: Theoretical Perspectives Undisciplined", pp. 3-34 in D. Spener and K. Staudt (eds.), The U.S.-Mexico Border: Transcending Divisions, Contesting Identities, Boulder, CO: Lynne Rienner.

Stokes, M. (1998) "Imagining 'the South': Hybridity, Heterotopia and Arabesk on the TurkishSyrian Border", pp. 263-289 in T. Wilson and H. Donnan (eds.), Border Identities: Nation and State at International Frontiers, Cambridge: Cambridge University Press.

Tsing, A. (1994) "From the Margins", Cultural Anthropology, 9(3): 279-297.

van Schendel, W. (2005a) "Spaces of Engagement: How Borderlands, Illicit Flows and Territorial States Interlock", pp. 38-68 in I. Abraham and W. van Schendel (eds.), Illicit Flows and Criminal Things: States, Borders, and the Other Side of Globalization, Bloomington: Indiana University Press.

van Schendel, W. (2005b) "Studying Borderlands", pp. 1-24 in The Bengal Borderlands: Beyond State and Nation in South Asia, London: Anthem Press.

Vila, Pablo (1997) "Narrative Identities: The Employment of the Mexican on the U.S.-Mexican Border", Sociological Quarterly, 38(1): 147-194.

Vila, Pablo (2000) Crossing Borders, Reinforcing Borders: Social Categories, Metaphors, and Narrative Identities on the U.S.-Mexico Frontier, Austin: University of Texas Press.

Vila, Pablo (2003) "Introduction: Border Ethnographies", pp. ix-xxxv in P. Vila (ed.), Ethnography at the Border (Cultural Studies of the Americas), Minneapolis: University of Minnesota.

Wilson, T. and Donnan, H. (1998) Border Identities: Nation and State at International Frontiers, Cambridge: Cambridge University Press.

Wong, D. (2005) "The Rumor of Trafficking: Border Controls, Illegal Migration, and the Sovereignty of the Nation-State", pp. 69-100 in W. van Schendel and I. Abraham (eds.), Illicit Flows and Criminal Things: States, Borders, and the Other Side of Globalization, Bloomington: Indiana University Press.

Yıldız, E . (2014) “Kaçak Pazarlar, Tutuk(lu) Hareketlilikler: Antep'in Iran Pazarı, Kaçağın Emeği ve Sınırötesilikleri Üzerine bir Deneme", Toplum ve Bilim, 131: 186-207.

Yükseker, D. (2007) "Shuttling Goods, Weaving Consumer Tastes: Informal Trade between Turkey and Russia", International Journal of Urban and Regional Research, 31(1): 60-72.

\section{Eşraf and esnaf}

Beşe, i . (2009) İşgalden-kurtuluşa Kilis: Aralık 1918-1921, Ankara: Via Design.

Beşe, i . (2012) "Cumhuriyet Tarihimizde Siyasi Yargılamalar ve Sonuçları", Kilis Postası, 17 December . Retrieved from www.kilispostasi.com/kose-yazisi/cumhuriyet-tarihimizde-siyasiyargilamalar-ve-sonuclari-ecz-ibrahim-bese/1200180; downloaded on 19 February 2014 . Bouchair, N. (1986) The Merchant and Moneylending Class of Syria Under the French Mandate, 1920-1946, unpublished PhD thesis, Georgetown University.

Canefe, N. (2002) "Turkish Nationalism and Ethno-Symbolic Analysis: The Rules of Exception", Nations and Nationalism, 8(2): 133-155.

Çolakoğlu, Ş . (1991) Kilis Direniş - Kurtuluş ve Sonrası 1918-1921-1930, Ankara: Feryal Matbaacılık.

Durakbaşa, A ., Karadağ, M . and Özsan, G . (2008) "Türkiye'de Taşra Burjuvazisinin Oluşum Sürecinde Yerel Eşrafın Rolü ve Taşra Kentlerinde Orta Sınıflar”, TÜBiTAK Project No: 105K174, Muğla Sıtkı Koçman Üniversitesi. 
Eroğlu, C. , Babuçoğlu, M. and Köçer, M. (2012) Osmanlı Vilayet Salnamelerinde Halep, Ankara: Orsam.

Gelvin, J. L. (2006) "The 'Politics of Notables' Forty Years After”, Middle East Studies Association Bulletin, 40(1): 19-29.

Gülcü, E. (2012) "Milli Mücadele Döneminde Kilis", Kilis 7 Aralık Üniversitesi Sosyal Bilimler Dergisi, 2(3): 1-37.

Hourani, A. (1993) "Ottoman Reform and the Politics of Notables", pp. 83-110 in A. Hourani , P. S. Khoury and M. C. Wilson (eds.), The Modern Middle East Reader, Berkeley: University of California Press.

Inalcık, H. (1991) "The Emergence of Big Farms, Ciftliks: State, Landlords, and Tenants", pp. 17-36 in Ç. Keyder and F. Tabak (eds.), Landholding and Commercial Agriculture in the Middle East, Albany, NY: State University of New York.

Ince, H. i. (2004) Milli Mücadele'de Kilis, unpublished MA thesis , Gaziantep: Gaziantep Üniversitesi.

Karadağ, M. (2005) Class, Gender and Reproduction: Exploration of Change in a Turkish City, unpublished PhD thesis, University of Essex.

Kevorkian, R. (2011) The Armenian Genocide: A Complete History, New York: I. B. Tauris. Keyder, Ç . (1987) State and Class in Turkey: A Study in Capitalist Development, London: Verso.

Keyder, Ç. (1991) "Introduction: Large-Scale Commercial Agriculture in the Ottoman Empire?", pp. 1-16 in Ç. Keyder and F. Tabak (eds.), Landholding and Commercial Agriculture in the Middle East, Albany, NY: State University of New York.

Keyder, Ç . (1999) "İmparatorluktan Cumhuriyete Geçişte Kayıp Burjuvazi Aranıyor”, Toplumsal Tarih, 68, pp. 4-11.

Khoury Philip , S. (1990) "The Urban Notables Paradigm revisited", Revue du monde musulman et de la Méditerranée, 55-56: 215-230.

Kıvrım, i. (2008) "Kilis ve A'zaz Voyvodası Daltaban-zâde Mehmed Ali Paşa ve Muhallefâtı", Ankara Üniversitesi Osmanlı Tarihi Araştırma ve Uygulama Merkezi Dergisi, 24: 147-174.

Köymen, O. (2009) "Kapitalizm ve Köylülük: Ağalar - Üretenler - Patronlar", Mülkiye, 35(262): 25-39.

Mardin, Ş. (1967) "Historical Determinants of Stratification: Social Class and Class

Consciousness in the Ottoman Empire", Siyasal Bilgiler Fakültesi Dergisi 22(4): 111-142.

Masters, B. (2010) "The Political Economy of Aleppo in an Age of Ottoman Reform, Journal of the Economic and Social History of the Orient, 53: 290-316

Meeker, M. (2002) A Nation of Empire: The Ottoman Legacy of Turkish Modernity, Berkeley: University of California Press.

Mizrahi, J. D. (2003) "Un « Nationalisme De La Frontière »: Bandes Armées Et Sociabilités Politiques Sur La Frontière Turco-Syrienne Au Début Des Années 1920," Vingtième Siècle. Revue d'histoire, 78, 19-34.

Öztürk, M. (2005) "İzziye Kazasının Kuruluşu ve Milli Mücadeledeki Yeri”, Ankara Üniversitesi Dil ve Tarih-Coğrafya Fakültesi Tarih Araştımaları Dergisi, 37: 29-45.

Roded, R. (1986) "The Syrian Urban Notables", Journal of the Israeli Orient Society: Asian and African Studies, 20(3): 375-384.

Şahin, A . (1999) "Giriş”, pp. 1-33 in Kilis'li Abdullah Sermest Tazebay Divanı: Metin-Inceleme, Uygur Tazebay.

Sayarı, S . (2011) "Clientelism and Patronage in Turkish Politics and Society", pp. 81-94 in B. Toprak and F. Birtek (eds.), The Post Modern Abyss and the New Politics of Islam: Assabiyah Revisited Essays in Honor of Şerif Mardin, Faruk, Istanbul: Bilgi University Press.

Timurtaş, K . ( Kilisli Kadri ) (1932) Kilis Tarihi, published by O. Vehbi, İstanbul: Bürhaneddin Matbaası.

Watenpaugh, K. (2003) "Middle-Class Modernity and the Persistence of the Politics of Notables in Inter-War Syria", International Journal of Middle East Studies, 35(2): 257-286.

Watenpaugh, K. (2005) "Cleansing the Cosmopolitan City: Historicism, Journalism and the Arab Nation in the Post-Ottoman Eastern Mediterranean", Social History, 30(1): 1-24.

Yazıksız, N. A. (Kilisli Balhasanoğlu Necip Asım) (1927) "Kilis Ocaklıları ile İki Hasbihal", Türk Yurdu, 5(28): 352-359.

Zhurzhenko, T. (2011) "Borders and Memory", pp. 63-84 in D. Wastl-Walter (ed.), The Ashgate Research Companion to Border Studies, Surrey: Ashgate. 


\section{Fall from grace}

Aswad, B. C. (1974) "Visiting Patterns among Women of the Elite in a Small Turkish City", Anthropological Quarterly: Visiting Patterns and Social Dynamics in Eastern Mediterranean Communities, 47(1): 9-27.

BCA (1931) Başbakanlık Cumhuriyet Arşivi (The State Archives of the Prime Minister's Office), 180/244/6, 5.12.1931.

Bebekoğlu, S . and Tektuna, M . (2008) Kilis kültür envanteri: kentsel mimari, kırsal mimari, yazıt eserleri, Kilis Valiliği.

Bertaux-Wiame, I. and Thompson, P. (1997) "The Familial Meaning of Housing in Social Rootedness and Mobility: Britain and France", pp. 124-182 in I. Bertaux-Wiame and P. Thompson (eds.), Pathways to Social Class: A Qualitative Approach to Social Mobility, Oxford: Clarendon Press.

Bouchair, N. (1986) The Merchant and Moneylending Class of Syria Under the French Mandate, 1920-1946, unpublished PhD thesis , Georgetown University.

Can, E. (2013) "Shifting boundaries and dynamics of neighbourhood: Women in public parks in Ankara", paper presented at International Resourceful Cities 21 Conference, 29-31 August.

Çetinoğlu, S . (2009) "Ermeni Emval-i Metrukeleri Üzerine”, Birikim, June 8.

Demir, E. (2006) "Toplumsal Değişme Süreci Içcinde Gençlik Parkı: Sosyolojik Bir

Değerlendirme", Şehir Plancıları Odası Planlama Dergisi, 4: 69-78.

Karadağ, M . (2005) Class, Gender and Reproduction: Exploration of Change in a Turkish City, unpublished PhD thesis, University of Essex.

Karadağ, M . (2009) "On Cultural Capital and Taste: Cultural Field in a Turkish City in Historical Perspective", European Societies, 11(4): 531-551.

Kesici, Ökkeş (1994) Kilis Yöresinin Coğrafyası, Ankara: Kilis Kültür Derneği Yayınları No. 12. Keyder, Ç . (1991) "Introduction: Large-Scale Commercial Agriculture in the Ottoman Empire?", pp. 1-16 in Ç. Keyder and F. Tabak (eds.), Landholding and Commercial Agriculture in the Middle East, Albany, NY: State University of New York.

Malpas, J. (2012) Heidegger and the Thinking of Place: Explorations in the Topology of Being, MIT Press.

Morley, D. (2001) "Belongings: Place, Space and Identity in a Mediated World", European Journal of Studies, 4(4): 425-448.

Newman, K. S. (1999) Falling from Grace: Downward Mobility in the Age of Affluence, Berkeley: University of California Press.

TBMM (1952) TBMM Tutanakları (Proceedings of TGNA), Vol. 17 Session 4, 14.11.1952.

TBMM (1966) TBMM Tutanakları (Proceedings of TGNA), Vol. 2, Session: 34, 12.1.1966.

TBMM (1968a) TBMM Tutanakları (Proceedings of TGNA), Vol. 28, Session: 74, p. 17, 10.6.1968.

TBMM (1968b) TBMM Cumhuriyet Senatosu Tutanakları (Proceedings of TGNA Republican Senate), Vol. 45 Session: 31, p. 1012, 8.2.1968.

Wilson, T. and Donnan, H. (1998) Border Identities: Nation and State at International Frontiers, Cambridge: Cambridge University Press.

Yeoh B. and Kong, L. (2006) "The Notion of Place in The Construction of History, Nostalgia and Heritage in Singapore", Singapore Journal of Tropical Geography, 17(1): 52-65.

\section{Wealth generation and the rise of new rich in the margins of economy and state}

Andreas, P. (2011) "Illicit Globalization: Myths, Misconceptions, and Historical Lessons", Political Science Quarterly, 126(3): 403-425.

Dündar, U. (2013) "Ürkütücü Gerçeği Açıklıyorum”, Sözcü, 21.12.2013.

Erdoğdu, A. (2013) "Dostluğun Mimarı Berber Yaşar çıktı”, Birgün, 23.12.2013.

Galemba, R. (2008) "Informal and Illicit Entrepreneurs: Fighting for a Place in the Neoliberal Economic Order", Anthropology of Work Review, 29(2): 19-25. 
Galemba, R. (2012a) "Taking Contraband Seriously: Practicing "Legitimate Work" at the Mexico-Guatemala Border", Anthropology of Work Review, 33(1): 3-14.

Galemba, R. B. (2013) "Illegality and Invisibility at Margins and Borders", Political and Legal Anthropology Review, 36(2): 274-285.

Gates, C. (1989) The Historical Role of Political Economy in the Development of Modern Lebanon, Oxford: Center for Lebanese Studies.

Green, S. (2009) "Of Gold and Euros: Locating Value on the Greek-Turkish Border", EastBordNet COST Action IS0803 Working Paper, 1-23.

Hatip-Karasulu, H. A. (2005) Making Sense of Mafia in Turkey: Conceptual Framework and a Preliminary Evaluation, unpublished PhD thesis, Boğaziçi University.

Hiçyılmaz, S . (2013) "Özal'dan Erdoğan'a Hortum İstikrarı", Evrensel, 24.12.2013.

Kahraman, A. (2013) "Berber Yaşar'ın Dönüşü”, Yeni Özgür Politika, 21.12.2013.

Keyder, Ç. (1987) State and Class in Turkey: A Study in Capitalist Development, London: Verso.

Mercan, F. (2002) "Bankama izin verilseydi şimdi bir numaraydım", Zaman, 4.6.2002; Retrieved 18 September 2014 from http://arsiv.zaman.com.tr/2002/06/04/haberler/h12.htm.

Milliyet (1988) "Kilis "Küçük Sicilya": Babaların 13'ü Kilisli”, Milliyet, 13.12.1988.

Naylor, R. (2004) Wages of Crime: Black Markets, Illegal Finance, and the Underworld Economy, Cornell University Press.

Nordstrom, C. (2000) "Shadows and Sovereigns", Theory, Culture and Society, 17(4): 35-54. Öniş, Z . (2004) "Turgut Özal and his Economic Legacy: Turkish Neo-Liberalism in Critical Perspective", Middle Eastern Studies, 40(4): 113-134.

Öniş, Z . and Webb, S . B. (1994) "Turkey: Democratization and Adjustment from Above", pp. 128-184 in S. Haggard and S. B. Webb (eds.), Voting for Reform: Democracy, Political Liberalization and Economic Adjustment, New York: Published for the World Bank, Oxford University Press.

Roitman, Janet (2004c) "The Garrison-Entrepôt: A Mode of Governing in the Chad Basin", pp. 417-436 in A. Ong and S. J. Collier (eds.), Global Assemblages: Technology, Politics, and Ethics as Anthropological Problems, Hoboken, NJ: Wiley-Blackwell.

Sağlam, M. H. (1991) Türkiye'de Altın Ticareti, unpublished MA thesis , i̇stanbul University. Tagliacozzo, E. (2007) "Thinking Marginally: Ethno-Historical Notes on the Nature of Smuggling in Human Societies", Journal of the Canadian Historical Association, 18(2): 144-163.

Tuşalp, E . (2005) "Otel Odası Pazarlamacıları”, Birgün, 24.9.2005.

Yetkin, Ç . (1989) "Türk Mafyasının Kasası İsviçre 1-7, Milliyet, 28.8.1989 - 3.10.1989.

Yükseker, D. (2003) Laleli-Moskova Mekiği: Kayıtdışı Ticaret ve Cinsiyet illişkileri, İletişim.

\section{Kilis as "little Beirut", markets and illegality}

Akdemir, i. O. and İncili, Ö. F. (2013) "Şehir Morfolojisi ve İktisadi Yapi Ilişkileri: XIX.Yüzyıl Kilis Şehri Örneği”, Kilis 7 Aralık Üniversitesi Sosyal Bilimler Dergisi, 3(6): 79-100.

Atalay-Güneş, Z. N. (2012) Theorizing 'Trust' in the Economic Field in the Era of Neoliberalism: The Perspectives of Entrepreneurs in Mardin, unpublished PhD thesis, METU, Ankara.

Bayraktar, F. (2003) Kilis ilii Uygun Yatırım Alanları Araştırması, Ankara: Türkiye Kalkınma Bankası Araştırma Müdürlüğü.

Bebekoğlu, S . and Tektuna, M . (2008) Kilis kültür envanteri: kentsel mimari, kırsal mimari, yazıt eserleri, Kilis Valiliği.

Benjamin, W. (2002) The Arcades Project, R. Tiedemann (ed.), H. Eiland and K. McLaughlin (trans.), New York: Belknap Press.

Bertaux-Wiame, I. and Thompson, P. (1997) "The Familial Meaning of Housing in Social Rootedness and Mobility: Britain and France", pp. 124-182 in D. Berteaux and P. Thompson (eds.), Pathways to Social Class: A Qualitative Approach to Social Mobility, Oxford: Clarendon Press.

Çolakoğlu, Ş . (1995) Kilis Tarihi Üzerine Deneme, Ankara: Kilis Kültür Derneği Yayınları. Galemba, R. (2012) "Taking Contraband Seriously: Practicing "Legitimate Work" at the MexicoGuatemala Border", Anthropology of Work Review, 33(1): 3-14. 
Gazete Kilis (2012) "Kilisliler Suriyeli Mülteci İstemiyor", 5.1.2012; Retrieved 17 May 2013 from www.gazetekilis.com/kilisliler-suriyeli-multecileri-istemiyor.

Green, S. (2009) "Of Gold and Euros: Locating Value on the Greek-Turkish Border", EastBordNet COST Action IS0803 Working Paper, 1-23.

Keyder, Ç . (1987) State and Class in Turkey: A Study in Capitalist Development, London: Verso.

Konyalı, i. H. (1968) Âbideleri ve kitâbeleri ile Kilis tarihi, Kilis Belediyesi.

Özgen, Neşe (2005) "Sınırın Iktisadi Antropolojisi: Suriye ve Irak Sınırlarında İki Kasaba", pp. 100-129 in B. Kümbetoglu and H. Birkalan-Gedik (eds.), Gelenekten Geleceğe Antropoloji, Epsilon Yayınları.

Pelkmans, M. (2006) Defending the Border: Identity, Religion, and Modernity in the Republic of Georgia (Culture and Society after Socialism), Ithaca, NY: University of Cornell Press.

Reeves, M. (2007) "Unstable objects: corpses, checkpoints and "chessboard borders" in the Ferghana valley", Anthropology of East Europe Review, 25(1): 72-84.

Roitman, Janet (2006) "The Ethics of Illegality in the Chad Basin", pp. 247-272 in J. Comaroff J . and J. Comaroff (eds.), Law and Disorder in the Postcolony, Chicago: University of Chicago Press.

Strathern, M. (1975) No Money on Our Skins: Hagen Migrants in Port Moresby, Port Moresby: New Guinea Research Unit Australian National University.

Taşçığlu, S. (2013) Tarihi Kentlerde Kimlik Sorunu: Kilis Örneği, unpublished MA thesis , Mustafa Kemal University, Hatay, Turkey.

Taşkesen, H. , Erke, F. , Bölükbaşı, I . H. and Karipçin, S. (2011) Kilis II Çevre Durum Raporu, Kilis: Kilis Valiliği Çevre ve Şehircilik il Müdürlüğü.

TBMM (1970) TBMM Tutanakları (Proceedings of TGNA), 28th legislative term, volume 5, 3rd period, 1st session, 26.5.1970.

TBMM (1977) TBMM Tutanakları (Proceedings of TNGA), 4th period, 4th session, 1977.

Yükseker, Deniz (2004) "Trust and Gender in a Transnational Market: The Public Culture of Laleli, Istanbul", Public Culture, 16(1): 47-65.

Yükseker, Deniz (2007) "Shuttling Goods, Weaving Consumer Tastes: Informal Trade between Turkey and Russia", International Journal of Urban and Regional Research, 31(1): 60-72.

\section{Peasantry turning into border laborers}

Abraham, I. and van Schendel, W. (2005) "Introduction: The Making of Illicitness" pp. 1-37 in I. Abraham and W. van Schendel (eds.), Illicit Flows and Criminal Things: States, Borders, and the Other Side of Globalization, Bloomington: Indiana University Press.

Akis, M. (2002) 16. Yüzyılda Kilis ve Azez Sancağında Iktisadi ve Sosyal Hayat, unpublished PhD thesis , Ankara University, Ankara.

Akis, M. (2004) "Tahrir Defterlerine Göre 16. Yüzyılda Kilis Sancağındaki Aşiretlerin İdareleri, Nüfusları ve Yaşamları", Tarih Araştırmaları Dergisi, 22(35): 9-31.

Altuğ, S. (2002) Between Colonial and National Dominations: Antioch under the French Mandate (1920-1939), unpublished MA thesis , Boğaziçi University, Istanbul.

Altuğ, S . and White, B . T. (2009) "Frontières et pouvoir d'État. La frontière turco-syrienne dans les années 1920 et 1930", Vingtième siècle, 103: 91-104.

Bayrak, M. (2012) "Suriye Kürtleri ve 1922 Mutabelatı", Kürt Tarihi Dergisi, 3: 48-55.

BCA (1931) Başbakanlık Cumhuriyet Arşivleri (The State Archives of the Prime Minister's Office), 180/244/6, 5.12.1931.

Bouchair, N. (1986) The merchant and moneylending class of Syria under the French Mandate, 1920-1946, unpublished PhD thesis, Georgetown University.

Bozçalı, F. (2010) The Illegal Oil Trade Along Turkey's Borders , MERIP, 41(261).

Bozçalı, F. (2014) "Hukuki-Maddi Bir Kategori Olarak Sınır: Türkiye-İran Sınırında Kaçakçılık, Mahkeme Süreçleri ve Sınırın 'Resmi' Temsilleri, Toplum ve Bilim, 131: 135-162.

Doevenspeck M. and Mwanabiningo, N. M. (2012) "Navigating Uncertainty: Observations from the Congo-Rwanda Border", pp. 85-106 in B. Bruns and J. Miggelbrink (eds.), Subverting Borders: Doing Research on Smuggling and Small-Scale Trade, Wiesbaden: VS Verlag für 
Sozialwissenschaften.

Donnan, H. and Wilson, T. (1999) Frontiers of Identity, Nation and State, Oxford, New York: Bloomsbury.

Flynn, Donna , K. (1997) "We Are the Border": Identity, Exchange, and the State along the Benin-Nigeria Border", American Ethnologist, 24(2): 311-330.

Galemba, R. B. (2012a) "Taking Contraband Seriously: Practicing 'Legitimate Work' at the Mexico-Guatemala Border", Anthropology of Work Review, 33(1): 3-14.

Galemba, R. B. (2012b) "Corn Is Food, not Contraband": The Right to 'Free Trade' at the Mexico-Guatemala Border", American Ethnologist, 38: 716-734.

Hernandez-Leon Ruben . 2008. Metropolitan Migrants, Berkeley: UCP.

Karadağ, M . (2005) Class, Gender and Reproduction: Exploration of Change in a Turkish City, unpublished PhD thesis, University of Essex, 2005.

Kesici, Ö . (1994) Kilis Yöresinin Coğrafyası, Ankara: Kilis Kültür Derneği Yayınları No. 12. Keyder, Ç . (1989) "Social structure and the labour market in Turkish agriculture", International Labour Review, 128(6): 731-744.

Kolay, G. (2012) "An Economy of Survival and Reinventing the Way of Life: The Case of Oil Commerce in Southeast Turkey" pp. 129-146 in B. Bruns and J. Miggelbrink (eds.), Subverting Borders: Doing Research on Smuggling and Small-Scale Trade, Wiesbaden: VS Verlag für Sozialwissenschaften.

Köymen, O. (2009) "Kapitalizm ve Köylülük: Ağalar - Üretenler - Patronlar”, Mülkiye, 35(262): 25-39.

Öğüt, Tahir (2010) "Milli Sınırların Oluşum Sürecinde Güneydoğu Anadolu'da Kaçakçılık Sorunu ile Dahiliye Vekili Şükrü Kaya Raporu ve Değerlendirilmesi", 1. Uluslararası Sınır Ticareti Kongresi Bildiriler Kitabı, İktisadi ve İdari Bilimler Fakültesi, Kilis 7 Aralık Üniversitesi, 4-6 Kasım.

Öniş, Ziya (2004) "Turgut Özal and his Economic Legacy: Turkish Neo-Liberalism in Critical Perspective", Middle Eastern Studies, 40(4): 113-134.

Özcan, Ö. (2014) "Yüksekova'da Sınır Deneyimleri: Bir "Sınır Kaçakçılığı" Hikâyesi ve Barış Süreci", Toplum ve Bilim, 131: 162-185.

Özgen, N. (2005) "Sınırın İktisadi Antropolojisi: Suriye ve Irak Sınırlarında İki Kasaba" pp. 100-129 in B. Kümbetoglu and H. Birkalan-Gedik (eds.), Gelenekten Geleceğe Antropoloji, Epsilon Yayınları.

Özgen, N . ( 2007 ) "Öteki'nin Kadını: Beden ve Milliyetçi Politikalar”, Türkiye'de Feminist Yaklaşımlar, no. 2. Retrieved from www.feministyaklasimlar.org/sayi-02-subat-2007/otekininkadini-beden-ve-milliyetci-politikalar/.

Özgen, N . (2012) "Kaçakçılığın ve Sınırın Öyküsü", Bianet, 14.1.2012. Retrieved 7 August 2014 from https://m.bianet.org/bianet/insan-haklari/135445-kacakciligin-ve-sinirin-oykusu.

Öztürk, M. (2005) "izziye Kazasının Kurulușu ve Milli Mücadeledeki Yeri”, Ankara Üniversitesi Dil ve Tarih-Coğrafya Fakültesi Tarih Araştımaları Dergisi, 37: 29-45.

Öztürk, N . (2006) "Türkiye'de Sınır Ticaretinin Gelişimi, Ekonomik Etkileri, Karşılaşılan Sorunlar ve Çözüm Önerileri”, ZKÜ Sosyal Bilimler Dergisi, 2(3): 107-127.

Parizot, C. (2014) "An Undocumented Economy of Control: Workers, Smugglers and State Authorities in Southern Israel/Palestine", pp. 93-112 in L. Anteby-Yemini , V. Baby-Collin and S. Mazzella (eds.), Borders, Mobilities and Migrations Perspectives from the Mediterranean 19-21st Century, Brussels: Peter Lang.

Roitman, Janet (2004a) "Introduction", pp. 1-22 in Fiscal Disobedience: An Anthropology of Economic Regulation in Central Africa, Princeton University Press.

Roitman, J. (2004b) "The Garrison-Entrepôt: A Mode of Governing in the Chad Basin", pp. 417-436 in A. Ong and S. J. Collier (eds.), Global Assemblages: Technology, Politics, and Ethics as Anthropological Problems, Malden and Oxford: Wiley-Blackwell.

Soyudoğan, M. (2005) Tribal Banditry in Ottoman Ayntab (1690-1730), unpublished MA thesis , Bilkent University.

TBMM (2003) TBMM Tutanakları (Proceedings of TGNA), 24th assembly, 1st session, 21.1.2003.

van Bruinessen, M. (2002) "Kurds, States and Tribes", pp. 165-183 in F. A. Jabar and H. Dawod (eds.), Tribes and Power: Nationalism and Ethnicity in the Middle East, London: Saqi. 


\section{"The border gate will not ever be closed"}

Aras, B. and Polat, R. K. (2008) "From Conflict to Cooperation: Desecuritization of Turkey's Relations with Syria and Iran", Security Dialogue, 39(5): 475-495.

Aydın, M. (2000) "Operasyonun adı var", Aksiyon, no. 309.

Aysu, A. (2013) "Türkiye tarımının serbest piyasaya uyarlanması ve küçük çiftçiliğin tasfiyesi”, in Perspectives - Political analysis and commentary from Turkey, issue no. 6 on "Grapes of Wrath - The Transformation of Agriculture and Rural Areas in Turkey" , Heinrich Böll Foundation, Istanbul.

Baransu, M. (2000) "Paraşüt açılmadı", Aksiyon, no. 288.

Bedirhanoğlu, P. (2007) "The Neoliberal Discourse on Corruption as a Means of Consent Building: Reflections from Post-crisis Turkey", Third World Quarterly, 28(7): 1239-1254.

Bozçalı, F. (2014) "Hukuki-Maddi Bir Kategori Olarak Sınır: Türkiye-İran Sınırında Kaçakçılık, Mahkeme Süreçleri ve Sınırın 'Resmi' Temsilleri, Toplum ve Bilim, 131: 135-162.

Buğra, A. and Keyder, Ç. (2006) "The Turkish Welfare Regime in Transformation", Journal of European Social Policy, 16(3): 211-228.

Dinçer, O. B. et al. (2013) Suriyeli Mülteciler Krizi ve Türkiye: Sonu Gelmeyen Misafirlik, Ankara: USAK and Brookings Institute.

Doğruel, F . and Karakoç, J . (2013) "The Regional Repercussions of Turkey-Syria Relations", Athens: ATINER'S Conference Paper Series, No: POL2013-0539.

Galemba R. B. (2012) "Taking Contraband Seriously: Practicing "Legitimate Work" at the Mexico-Guatemala Border", Anthropology of Work Review, 33(1): 3-14.

Galemba, R. B. (2013) "Illegality and Invisibility at Margins and Borders", Political and Legal Anthropology Review, 36(2): 274-285.

Gupta, A. (1995) "Blurred Boundaries: The Discourse of Corruption, the Culture of Politics, and the Imagined State", American Ethnologist, 22(2): 375-402.

Heyman, J . McC. and Cambell, H . (2007) "Corruption in the U.S. Borderlands with Mexico: The 'Purity' of Society and the 'Perversity' of Borders", pp. 191-217 in M. Nuijten and G. Anders (eds.), Corruption and the Secret of Law: A Legal Anthropological Perspective, Aldershot: Ashgate.

Hürriyet (2000a) "Bürokrat Avı", 31.6.2000 . Retrieved 23 January 2018 from

www.hurriyet.com.tr/burokrat-avi-39158267.

Hürriyet (2000b) "500 trilyonu aşabilir", 30.6.2000. Retrieved 23 January 2018 from www.hurriyet.com.tr/500-trilyonu-asabilir-39158012.

Keyder, Ç. and Yenal, Z. (2011) "Agrarian Change under Globalization: Markets and Insecurity in Turkish Agriculture", Journal of Agrarian Change, 11(1): 60-86.

Kilis İ Çevre Durum Raporu, Şehir Planlama ve Çevre îl Müdürlüğü, Kilis Valiliği , 2011.

NTV (2001) "Paraşütte yeni tutuklamalar", NTV, 8.5.2001 . Retrieved 23 January 2018 from http://arsiv.ntv.com.tr/news/81588.asp.

Official Gazette no. 25173 , 19.7.2003.

Official Gazette no. 26479 , 31.3.2007.

Official Gazette no 28170 , 11.1.2012.

Özden, Ş . (2013) Syrian Refugees in Turkey, Migration Policy Center Research Report 2013/05, San Domenico di Fiesole: European University Institute.

Parizot, C. (2008) "Crossing Borders, Retaining Boundaries: Kin-nections of Negev Bedouin in Gaza, West Bank, and Jordan", pp. 58-84 in S. Hanafi (ed.), Crossing Borders, Shifting Boundaries: Palestinian Dilemmas, Cairo: American University in Cairo Press.

Reeves, M. (2007) "Unstable Objects: Corpses, Checkpoints and "Chessboard Borders" in the Ferghana Valley", Anthropology of East Europe Review, 25(1): 72-84.

TBMM (1999) TBMM Tutanakları (Proceedings of TGNA), 21st period, 2nd legislation year, 7th assembly, p. 10, 14.10.1999.

van Bruinessen, M. (2002) "Kurds, States and Tribes", pp. 165-183 in F. A. Jabar and H. Dawod (eds.), Tribes and Power: Nationalism And Ethnicity in the Middle East, London: Saqi. Watenpaugh, K. (2005) "Cleansing the Cosmopolitan City: Historicism, Journalism and the Arab Nation in the Post-Ottoman Eastern Mediterranean", Social History, 30(1): 1-24.

Yeni Şafak (1999) "Bayramlaşmada tel örgü engeli kalkacak", 15.6.1999 . Retrieved from www.yenisafak.com/gundem/bayramlasmada-tel-orgu-engeli-kalkacak-586999. 
Yeni Şafak (2000) "Bir İsim Bir Operasyon", 23.8.2000. Retrieved 23 January 2018 from www.yenisafak.com/arsiv/2000/agustos/23/g3.html.

Yeni Şafak (2000) "Gaziantep'e İnen ‘Paraşüt'-1: Muzun dayanılmaz cazibesi”, 6.1.2000. Retrieved 23 January 2018 from www.yenisafak.com/arsiv/2000/haziran/06/dizi.html. Zafar, Shaista Shaheen (2012) “Turkey's 'Zero Problems with Neighbours' Foreign Policy; Relations with Syria", Journal of European Studies, 28(1): 143-158.

\section{Conclusion}

Bulut, Ş . (1991) [1970] Kaçakçı Şahan, İstanbul: Everest Yayınları.

Galemba, R. B. (2008) "Informal and Illicit Entrepreneurs: Fighting for a Place in the Neoliberal Economic Order", Anthropology of Work Review 29(2): 19-25.

Galemba, R. B. (2012a) "Taking Contraband Seriously: Practicing 'Legitimate Work' at the Mexico-Guatemala Border", Anthropology of Work Review 33(1): 3-14.

Galemba, R. B. (2012b) "Corn Is Food, not Contraband": The Right to "Free Trade" at the Mexico-Guatemala border", American Ethnologist, 39(4): 716-734.

Karadağ, M. (2005) Class, Gender and Reproduction: Exploration of Change in a Turkish City, unpublished PhD thesis, University of Essex.

Meeker, M. (2002) A Nation of Empire: The Ottoman Legacy of Turkish Modernity, Berkeley: University of California Press.

Parizot, C. (2014) "An Undocumented Economy of Control: Workers, Smugglers and State Authorities in Southern Israel/Palestine", pp. 93-112 in L. Anteby-Yemini , V. Baby-Collin and S. Mazzella (eds.), Borders, Mobilities and Migrations Perspectives from the Mediterranean 1921st Century, Brussels: Peter Lang.

Pelkmans, M. (2006) Defending the Border: Identity, Religion, and Modernity in the Republic of Georgia (Culture and Society after Socialism), University of Cornell Press.

Roitman, J. (2004) Fiscal Disobedience: An Anthropology of Economic Regulation in Central Africa, Princeton University Press.

Roitman, J. (2006) "The Ethics of Illegality in the Chad Basin", pp. 247-272 in J. Comaroff and J. Comaroff . (eds.), Law and Disorder in the Postcolony, University of Chicago Press.

\section{Epilogue}

AFAD (2017) Geçici Barınma Merkezi Raporları, 11.12.2017. Retrieved 22 December 2017 from www.afad.gov.tr/upload/Node/2374/files/11_12_2017_Suriye_GBM_Bilgi_Notu.pdf. Al (Amnesty International) (2014) Struggling to Survive Refugees from Syria In Turkey, London: Amnesty International.

Al-Abed, O. (2014) "The Discourse of Guesthood: Forced Migrants in Jordan", pp. 81-100 in A. Fábos , A. and R. Isotalo , Managing Muslim Mobilities, London: Palgrave MacMillan.

Aljazeera (2014) "Kilis'de Suriyeliler tahliye edildi", 15.8.2014. Retrieved 8 December 2017 from www.aljazeera.com.tr/haber/kiliste-de-suriyeliler-tahliye-edildi.

Al-Tamimi, A. J. (2015), Special Report: Northern Storm and the Situation in Azaz (Syria), Middle East Review of International Affairs (MERIA Journal). Retrieved 25 December 2017 from www.aymennjawad.org/15865/special-report-northern-storm-and-the-situation.

Ay, M. (2014) The Mass Influx of Syrian Refugees to Turkey, Emergency and Disaster Reports, University of Oviedo, 1(2): 2-53.

Baban, F. , Ilcan, Z. and Rygiel, K. (2016) "Syrian Refugees in Turkey: Pathways to Precarity, Differential Inclusion, and Negotiated Citizenship Rights", Journal of Ethnic and Migration Studies, 43(1): 41-57.

Balanche, F. (2014) "Alep et ses territoires: une métropole syrienne dans la mondialisation", pp. 39-65 in J. David and T. Boissière , (eds.), Alep et Ses Territoires: Fabrique et politique d'une ville (1868-2011), Presse de l'Ifpo. 
Balcılar, M . and Nugent, J . B. (2018) The Migration of Fear: An Analysis of Migration Choices of Syrian Refugees, Discussion Paper 15-36, Fagamusta, Eastern Mediterranean University, North Cyprus.

Biehl, K. et al. (2016) Needs assessment Report: Technical Assistance for a comprehensive needs assessment of short and medium to long term actions as basis for an enhanced EU support to Turkey on the refugee crisis, Service Contract No. 2015/366838,

EUROPEAID/129783/C/SER/multi, European Commission. Retrieved 24 January 2018 from www.avrupa.info.tr/fileadmin/Content/2016_April/160804_NA_report_FINAL_VERSION.pdf. Bilefsky, D . and Arsu, Ş . (2010) "Sponsor of Flotilla Tied to Elite of Turkey", The New York Times, 15.7.2010 . Retrieved 25 January 2018 from www.nytimes.com/2010/07/16/world/middleeast/16turkey.html?_r=1.

Brun, C. (2010) "Hospitality: Becoming 'IDPs' and 'Hosts' in Protracted Displacement", Journal of Refugee Studies, 23(3): 337-355.

Cagaptay, S. (2014) The Impact of Syrian Refugees on Southern Turkey, Policy Focus 130, The Washington Institute for Near East Policy, Washington , pp. 1-32.

Carpi, E. (2016) "Against Ontologies of Hospitality. About Syrian Refugeehood in Northern Lebanon", Middle East Institute . Retrieved 12 December 2017 from www.mei.edu/content/map/against-ontologies-hospitality-about-syrian-refugeehood-northernlebanon.

Carpi, E . and Şenoğuz, P . H. (2018) "Refugee Hospitality in Lebanon and Turkey: On Making the 'Other'”, Special Issue on Syrian Refugees: Facing Challenges, Making Choices, International Migration Journal, forthcoming.

Chatty, D. (2017) "The Duty to Be Generous (Karam): Alternatives to Rights-Based Asylum in the Middle East", Journal of the British Academy, 5: 177-199.

CNN Türk (2016) “Kilis Nobel Barış Ödülü'ne Aday”, 7.3.2013. Retrieved 24 December 2017 from www.cnnturk.com/turkiye/kilis-nobel-baris-odulune-aday.

Dağtaş, S. (2017) "Whose Misafirs? Negotiating Difference along the Turkish-Syrian Border", International Journal of Middle East Studies, 49: 661-679.

Del Carpio , X. D. and Wagner, M. (2015) The Impact of Syrian Refugees on the Turkish Labor Market, Policy Research Working Paper 7402, World Bank .

Deniz, Ç . A., Ekinci Y . and Hülür, B . (2016) "Bizim Müstakbel Hep Harap Oldu": Suriyeli sığınmacıların gündelik hayatı, Antep-Kilis çevresi, İstanbul: Bilgi Üniversitesi Yayınları.

Derrida, J. (2011) The Principle of Hospitality, Parallax, 11(1): 6-9.

Dinçer, O. B. et al. (2013) Suriyeli Mülteciler Krizi ve Türkiye: Sonu Gelmeyen Misafirlik, Ankara: USAK and Brookings Institute.

ECPAT (2015) Global Monitoring: Status of Action against Commercial Sexual Exploitation of Children, 2nd Edition, ECPAT International (End Child Prostitution, Child Pornography and Trafficking of Children for Sexual Purposes) .

Erdoğan, M. (2014) "Perception of Syrians in Turkey", Insight Turkey, 16(4): 65-75.

Erkoç, T. (2013) "Refugee-Asylum Seeker Policy of Turkey in The Light of Recent

Developments", pp. 39-44 in E. Akçay and F. Alimukhamedov (eds.), Refugee-Asylum Seeker

Policy of Turkey in the Light of Recent Developments, Workshop Proceedings, Ankara: The Journalists and Writers Foundation Press,

EU (2016) EU Humanitarian Implementation Plan - Syrian Regional Crisis, Ref. Ares (2016)1865591 - 20/04/2016. Retrieved 25 January 2018 from

http://ec.europa.eu/echo/files/funding/decisions/2016/HIPs/HIP\%20V2\%20FINAL.pdf. Evron, Y. (2016) "Can China Participate in Middle East Stabilization Efforts by Supporting Regional Connectivity?", Asia Pacific Bulletin, no. 363.

Ferris, E . and Kirişçi, K . (2015) From Turkey to Syria: The Murky World of Cross-border assistance, The Brookings Institution. Retrieved 23 December 2017 from

www.brookings.edu/opinions/from-turkey-to-syria-the-murky-world-of-cross-border-assistance/. Girit, S. (2016) "Syria Conflict: Kilis, the Turkish Town Enduring IS Bombardment", BBC, 9 May 2016. Retrieved 14 November 2017 from www.bbc.com/news/world-europe-36245505.

Green, S. (2012) "A Sense of Border: The Story So Far", pp. 573-592 in T. M. Wilson and H. Donnan (eds.), A Companion to Border Studies, Chichester: Wiley-Blackwell.

Hamdan, A. (2017) "Stretched Thin: Geographies of Syria's Opposition in Exile", Refugees and Migration Movements in the Middle East, University of California Press, Berkeley. Retrieved 25 November 2017 from https://pomeps.org/wp- 
content/uploads/2017/03/POMEPS_Studies_25_Refugees_Web.pdf.

Heck, G. and Hess, S. (2017) "Tracing the Effects of the EU-Turkey Deal: The Momentum of the Multi-Layered Turkish Border Regime", Movements: Journal for Critical Migration and Border Regime Studies, 3(2): 35-56.

Herwig, R. (2017) "Strategies of Resistance of Syrian Female Refugees in Şanlıurfa", Movements: Journal for Critical Migration and Border Regime Studies, 3(2): 177-192.

Hürriyet (2016) "Gaziantep-Kilis Arasındaki OSB'ye Bakanlıktan Onay", 14.10.2016. Retrieved 14 November 2017 from www.hurriyet.com.tr/gaziantep-kilis-arasindaki-osbye-bakanliktan-o40248929.

Hürriyet Daily News (2016) "AKP Moves to Nominate Turkish Town Hosting Syrians for Nobel Prize", 8.2.2017. Retrieved 24 January 2018 from www.hurriyetdailynews.com/akp-moves-tonominate-turkish-town-hosting-syrians-for-nobel-prize-94882.

ICGG (2013) Blurring the Borders: Syrian Spillover Risks for Turkey, Report No. 225, 30 April 2013.

Ilgit, A . and Davis, R . (2013) The Many Roles of Turkey in the Syrian Crisis, Merip, January 28, 2013. Retrieved 21 January 2018 from www.merip.org/mero/mero012813.

İdiz, S . (2018) "Erdogan scores big with Afrin operation, but problems remain", Al-Monitor, 23 January 2018. Retrieved 25 January 2018 from: www.al-

monitor.com/pulse/originals/2018/01/turkey-syria-erdogan-scores-big-with-afrin-operation.html. IRIN News (2015) "Turkish NGO Move Boosts Syria Aid Delivery", 25.6.2015. Retrieved 25 January 2018 from www.irinnews.org/news/2015/06/25/turkish-ngo-move-boosts-syria-aiddelivery.

Kavak, S. (2016) "Syrian Refugees in Seasonal Agricultural Work: A Case of Adverse Incorporation in Turkey", New Perspectives on Turkey, 54: 33-53.

Kaymaz, T. and Kadkoy, T. (2016) Syrians in Turkey - The Economics of Integration, Alsharq Forum Expert Brief .

Kıvılcım, Z. (2016) "Legal Violence against Female Syrian Refugees in Turkey", Feminist Legal Studies, 24(2): 193-214.

Kilis Postası (2014) Kilis'te Taksi Durakları Artıyor, 26.11.2014. Retrieved 25 January 2018 from www.kilispostasi.com/kilis-te-taksi-duraklari-artiyor/1207690/.

Kilis'teki Suriye: Sorunların Tespitine ve Çözümlerine Illişkin Rapor, Kilis Ortak Akıl Topluluğu, 2013.

Kravitz, M. and Nichols, W. (2016) "A Bitter Pill to Swallow: Connections Between Captagon, Syria, and the Gulf", Journal of International Affairs, 18.5.2016. Retrieved 13 September 2017 from https://jia.sipa.columbia.edu/bitter-pill-swallow-connections-captagon-syria-gulf.

Mazlum-Der (2014) Report on Syrian Women Refugees Living Out of the Camps, Mazlum-Der Women Studies Group . Retrieved 25 January 2018 from

http://istanbul.mazlumder.org/webimage/report-of-syrian-women-refugees-living-out-of-thecamps.pdf.

McClelland, M. (2014) "How to Build a Perfect Refugee Camp", The New York Times, 13

February 2014. Retrieved 24 January 2018 from www.nytimes.com/2014/02/16/magazine/howto-build-a-perfect-refugee-camp.html.

MMP [Mixed Migration Platform] (2017) Refugee, Asylum-Seeker and Migrant Perception in Gaziantep and Kilis, 29 June 2017. Retrieved 25 December 2017 from

http://groundtruthsolutions.org/wp-content/uploads/2017/07/MMP_Turkey_R1_Gaziantep.pdf. Montabone, B. (2016) "The Wartime Emergence of a Transnational Region Between Turkey and Syria", pp. 181-198, in L. Vignal (ed.), The Transnational Middle East: People, Places, Borders, Oxford, New York: Routledge.

Moore, P. and Parker, C. (2007) "The War Economy of Iraq", MERIP, Vol. 37.

NTV (2012) “Erdoğan'dan Suriyelilere: Zaferiniz uzak değil”, 6.5.2012. Retrieved 17 December 2017 from www.ntv.com.tr/turkiye/erdogandan-suriyelilere-zaferiniz-uzak-

degil,eh4IpDgi20OApyeeBVBIdQ.

OCHA (2014) Humanitarian Bulletin: Syria Operations from Turkey, Issue 4, 20 Sept - 03 Oct 2014. Retrieved 25 January 2018 from

www.humanitarianresponse.info/system/files/documents/files/20141003_Humanitarian\%20Bulle tin.pdf.

OCHA (2017) Fact Sheet: United Nations Cross-border Operations from Turkey to Syria.

Retrieved 25 January 2018 from 
www.humanitarianresponse.info/system/files/documents/files/20170331_fact_sheet_unscr21652191-2258.pdf.

Okyay, A. (2017) "Turkey's Post-2011 Approach to its Syrian Border and its Implications for Domestic Politics", International Affairs, 93(4): 829-846.

Orhan, O . and Gündoğar, S . S. (2015) Effects of the Syrian Refugees on Turkey, Orsam

Report No: 195. Retrieved 25 January 2018 from

www.orsam.org.tr/files/Raporlar/rapor195/195eng.pdf.

Özden, Ş . (2013) Syrian Refugees in Turkey, Migration Policy Center Research Report 2013/05, San Domenico di Fiesole: European University Institute.

Özpınar, E. , Başıhoş, S. and Kulaksız, A. (2015) Trade Relations with Syrian after the Refugee Influx, TEPAV Report, No. 201527.

Öztürkler, H. and Göksel, T. (2015) The Economic Effects of Syrian Refugees on Turkey: A Synthetic Modelling, Orsam Report, No. 196.

Paksoy, M. et al. (2015) Suriyelilerin Ekonomik Etkisi: Kilis ilii Örneği, Birey ve Toplum, 5(9): 143-173.

Plonski, S. (2017) The Ontology of a "Train to Nowhere", Border, Fences, Wirewalls: Assesing the Changing Relationship of Territory and Institutions, Max Planck Institute for the Study of Religious and Ethnic Diversity, Göttingen, Germany, 19-20 October.

REACH (2014) Syria crisis: Camps and informal Settlements in Northern Syria, Humanitarian baseline review, June. Retrieved 25 January 2018 from https://reliefweb.int/report/syrian-arabrepublic/syria-crisis-camps-and-informal-settlements-northern-syria-humanitarian.

Rozakou, K. (2012) "The Biopolitics of Hospitality in Greece. Humanitarianism and the Management of Refugees", American Ethnologist, 39(3): 562-577.

Şenoğuz, P. H. (2017) "Border Contestations, Syrian Refugees and Violence in the Southeastern Margins of Turkey", Movements: Journal for Critical Migration and Border Regime Studies, 3(2): 163-176.

Shaheen, K. (2016) "MSF Stops Sharing Syria Hospital Locations after 'Deliberate' Attacks", Guardian, 18 February 2016. Retrieved 20 January 2018 from

www.theguardian.com/world/2016/feb/18/msf-will-not-share-syria-gps-locations-after-deliberateattacks.

Şimşek, D . (2015) "Anti-Syrian Racism in Turkey”, Open Democracy, 27.1.2015. Retrieved 31 October 2017 from www.opendemocracy.net/north-africa-west-asia/dogus-simsek/antisyrianracism-in-turkey.

Soykan, C. (2016) "Turkey as Europe's Gatekeeper - Recent Developments in the Field of Migration and Asylum and the EU-Turkey Deal of 2016", pp. 52-60 S. Hess et al. (eds.), Der Lange Sommer der Migration: Grenzregime III, Assoziation A.

Taştekin, F . (2016) "How the Islamic State Is Still Sweeping Through Syria-Turkey Border", AlMonitor, 1.2.2016. Retrieved 28 December 2017 from www.al-

monitor.com/pulse/originals/2016/02/turkey-syria-greedy-smugglers-islamic-state.html.

Toğral Koca , B. (2015) Deconstructing Turkey's "Open Door" Policy towards Refugees from Syria, Migration Letters, 12(3): 209-225.

UNHCR (2015) Global Trends: Forced Displacement in 2015. Retrieved 25 January 2018 from www.unhcr.org/576408cd7.pdf.

Vallet, E. and David, C. (2012) "Introduction: The (Re)Building of the Wall in International Relations," Journal of Borderlands Studies, 27(20): 111-119.

Vignal, L. (2017) "The Changing Borders and Borderlands of Syria in a Time of Conflict", International Affairs, 93(4): 809-827.

Walters, W. (2011) "Foucault and Frontiers: Notes on the Birth of the Humanitarian Border", pp. 138-164 in U. Bröckling , S. Krassman and T. Lemke (eds.), Governmentality: Current Issues and Future Challenges, London: Routledge.

World Bank (2015) Turkey's Response to the Syrian Refugee Crisis and the Road Ahead, No. 102184. Retrieved 25 January 2018 from

http://documents.worldbank.org/curated/en/583841468185391586/pdf/102184-WP-P151079-

Box394822B-PUBLIC-FINAL-TurkeysResponseToSyrianRefugees-eng-12-17-15.pdf.

Yaşar, R. M. (2014) Kilis'te Sığınmacı Algısı: Toplumsal Otizm ve Ötekileştirme Sürecinin İlk Görünümleri, Kilis: Kilis 7 Aralık Üniversitesi Matbaası. 